\title{
Measurement of $\mathrm{OH}$ reactivity by laser flash photolysis coupled with laser-induced fluorescence spectroscopy
}

\author{
Daniel Stone $^{1}$, Lisa K. Whalley ${ }^{1,2}$, Trevor Ingham ${ }^{1,2}$, Peter M. Edwards ${ }^{1, a}$, Danny R. Cryer ${ }^{1}$, Charlotte A. Brumby ${ }^{1}$, \\ Paul W. Seakins ${ }^{1,2}$, and Dwayne E. Heard ${ }^{1,2}$ \\ ${ }^{1}$ School of Chemistry, University of Leeds, Leeds, LS2 9JT, UK \\ ${ }^{2}$ National Centre for Atmospheric Science (NCAS), University of Leeds, Leeds, LS2 9JT, UK \\ ${ }^{a}$ now at: Wolfson Atmospheric Chemistry Laboratories, Department of Chemistry, University of York, \\ Heslington, York, YO10 5DD, UK
}

Correspondence to: Dwayne E. Heard (d.e.heard@leeds.ac.uk)

Received: 14 February 2016 - Published in Atmos. Meas. Tech. Discuss.: 29 February 2016

Revised: 3 June 2016 - Accepted: 8 June 2016 - Published: 7 July 2016

\begin{abstract}
OH}$ reactivity $\left(k_{\mathrm{OH}}^{\prime}\right)$ is the total pseudo-first-order loss rate coefficient describing the removal of $\mathrm{OH}$ radicals to all sinks in the atmosphere, and is the inverse of the chemical lifetime of $\mathrm{OH}$. Measurements of ambient $\mathrm{OH}$ reactivity can be used to discover the extent to which measured $\mathrm{OH}$ sinks contribute to the total $\mathrm{OH}$ loss rate. Thus, $\mathrm{OH}$ reactivity measurements enable determination of the comprehensiveness of measurements used in models to predict air quality and ozone production, and, in conjunction with measurements of $\mathrm{OH}$ radical concentrations, to assess our understanding of $\mathrm{OH}$ production rates. In this work, we describe the design and characterisation of an instrument to measure $\mathrm{OH}$ reactivity using laser flash photolysis coupled to laserinduced fluorescence (LFP-LIF) spectroscopy. The LFP-LIF technique produces $\mathrm{OH}$ radicals in isolation, and thus minimises potential interferences in $\mathrm{OH}$ reactivity measurements owing to the reaction of $\mathrm{HO}_{2}$ with $\mathrm{NO}$ which can occur if $\mathrm{HO}_{2}$ is co-produced with $\mathrm{OH}$ in the instrument. Capabilities of the instrument for ambient $\mathrm{OH}$ reactivity measurements are illustrated by data collected during field campaigns in London, UK, and York, UK. The instrumental limit of detection for $k_{\mathrm{OH}}^{\prime}$ was determined to be $1.0 \mathrm{~s}^{-1}$ for the campaign in London and $0.4 \mathrm{~s}^{-1}$ for the campaign in York. The precision, determined by laboratory experiment, is typically $<1 \mathrm{~s}^{-1}$ for most ambient measurements of $\mathrm{OH}$ reactivity. Total uncertainty in ambient measurements of $\mathrm{OH}$ reactivity is $\sim 6 \%$. We also present the coupling and characterisation of the LFPLIF instrument to an atmospheric chamber for measurements of $\mathrm{OH}$ reactivity during simulated experiments, and provide
\end{abstract}

suggestions for future improvements to OH reactivity LFPLIF instruments.

\section{Introduction}

$\mathrm{OH}$ radicals dominate atmospheric oxidation chemistry, controlling the lifetimes of most primary pollutants and greenhouse gases emitted into the atmosphere, including methane, $\mathrm{CO}$, volatile organic compounds (VOCs), $\mathrm{NO}_{2}$ and $\mathrm{SO}_{2}$, whilst also contributing to the production of secondary pollutants such as ozone, sulphuric acid and secondary organic aerosol (SOA) (Stone et al., 2012). Appreciation of the factors controlling atmospheric $\mathrm{OH}$ radical concentrations is thus essential to understanding the processing and fate of trace species in the atmosphere, and to our ability to understand and predict air quality and climate change. Moreover, the short chemical lifetimes of the $\mathrm{OH}$ radical and the closely related $\mathrm{HO}_{2}$ radical make $\mathrm{OH}$ and $\mathrm{HO}_{2}$ ideal species for testing the chemical mechanisms used in atmospheric models since their concentrations are controlled by in situ chemistry alone and are not influenced by transport processes. However, model simulations of $\mathrm{OH}$ concentrations require calculation of both $\mathrm{OH}$ production and loss rates, and there is potential for agreement between modelled and observed $\mathrm{OH}$ concentrations based on opposing errors in the production and loss terms. Similarly, when model calculations show poor agreement with observations, it can be problematic to determine whether the model discrepancies result from in- 
complete knowledge of the total production rate or of the total loss rate.

Observations of $\mathrm{OH}$ radical concentrations made in conjunction with measurements of $\mathrm{OH}$ reactivity $\left(k_{\mathrm{OH}}^{\prime}\right)$, the total loss rate of $\mathrm{OH}$ and the inverse of the $\mathrm{OH}$ chemical lifetime $\left(\tau_{\mathrm{OH}}\right)$ thus provide a means to separate the production and loss terms for $\mathrm{OH}$, enabling a more robust test of our understanding of $\mathrm{OH}$ radical concentrations and of atmospheric oxidation chemistry. In addition, comparison of measured $\mathrm{OH}$ reactivity with calculated $\mathrm{OH}$ reactivity, based on observed concentrations of $\mathrm{OH}$ sinks and known rate coefficients for their reactions with $\mathrm{OH}$ (Eq. 3), also provides an indication of the presence and importance of unmeasured $\mathrm{OH}$ sinks:

$-\mathrm{d}[\mathrm{OH}] / \mathrm{d} t=\Sigma k_{x}[\mathrm{X}][\mathrm{OH}]$

$=k_{\mathrm{OH}}^{\prime}[\mathrm{OH}]$

$k_{\mathrm{OH}}^{\prime}=\Sigma k_{x}[\mathrm{X}]$,

where $k_{x}$ is the rate coefficient for reaction of $\mathrm{OH}$ with species $\mathrm{X}$ and $k_{\mathrm{OH}}^{\prime}$ is the $\mathrm{OH}$ reactivity (the pseudo-firstorder rate coefficient for reaction of $\mathrm{OH}$ with all reaction partners present). Finally, using both $[\mathrm{OH}]$ and $k_{\mathrm{OH}}^{\prime}$ to determine $-\mathrm{d}[\mathrm{OH}] / \mathrm{d} t$ experimentally, it is possible to evaluate the completeness of our knowledge of $\mathrm{OH}$ sources, which when added together should equal $+\mathrm{d}[\mathrm{OH}] / \mathrm{d} t$ if the steadystate budget is closed (Martinez et al., 2003; Whalley et al., 2011; Fuchs et al., 2013; Lu et al., 2013).

Measurements of $\mathrm{OH}$ reactivity in the atmosphere have been made by three different techniques - the flow tube technique, the laser flash photolysis technique and the comparative reactivity method, with all three methods relying on production of above ambient concentrations of $\mathrm{OH}$ radicals and monitoring of the $\mathrm{OH}$ decay rate, either directly or indirectly. The flow tube method (Kovacs and Brune, 2001) typically generates $\mathrm{OH}$ radicals at the tip of a sliding injector by photolysis of water vapour (Reaction R1) using a mercury vapour lamp, also resulting in production of $\mathrm{HO}_{2}$ radicals (Reaction R2).

$$
\begin{aligned}
& \mathrm{H}_{2} \mathrm{O}+\mathrm{h} v \rightarrow \mathrm{H}+\mathrm{OH} \\
& \mathrm{H}+\mathrm{O}_{2}(+\mathrm{M}) \rightarrow \mathrm{HO}_{2}(+\mathrm{M})
\end{aligned}
$$

The $\mathrm{OH}$ radical signal is monitored downstream of the injector after mixing with a flow of ambient air in the main tube. By changing the position of the sliding injector relative to the point at which $\mathrm{OH}$ is detected it is possible to vary the contact time of $\mathrm{OH}$ with the ambient air, and thus to determine the total loss rate for $\mathrm{OH}$ in the flow tube. However, the technique has a number of disadvantages. The time resolution of measurements made by the flow tube method is relatively poor, owing to the need to measure $\mathrm{OH}$ signals at a number of different injector positions to obtain a kinetic profile, during which time the ambient $\mathrm{OH}$ reactivity could show significant variability, although Mao et al. (2009) overcome this issue for airborne measurements of $\mathrm{OH}$ reactivity by reducing the number of time points used to determine the $\mathrm{OH}$ decay rate. The flow rates of sampled air in the flow tube method are relatively high $\left(\sim 300-900\right.$ standard $\left.\mathrm{L} \mathrm{min}^{-1}\right)$, with turbulent flow conditions leading to high wall loss rates of $\mathrm{OH}$ in the flow tube and relatively high uncertainties in determinations of $\mathrm{OH}$ reactivity owing to uncertainties in the wall loss rates. Knowledge of the flow velocity in the flow tube, requiring direct measurement or knowledge of the flow regime, total flow rate and cross-section of the flow tube, is also needed to convert the distance over which $\mathrm{OH}$ and ambient air are mixed to reaction time, and can lead to uncertainties in the contact time between $\mathrm{OH}$ and reactants in ambient air. A significant disadvantage of the flow tube method is the generation of equal concentrations of $\mathrm{OH}$ and $\mathrm{HO}_{2}$ following photolysis of water vapour at the tip of the sliding injector (Reactions R1$\mathrm{R} 2$ ), leading to the potential for production of $\mathrm{OH}$ in the flow tube on the timescale of the experiment owing to the reaction of $\mathrm{HO}_{2}$ with ambient $\mathrm{NO}$ (Reactions R3).

$\mathrm{HO}_{2}+\mathrm{NO} \rightarrow \mathrm{OH}+\mathrm{NO}_{2}$

The production of $\mathrm{OH}$ from Reaction (R3) reduces the observed decay rate of $\mathrm{OH}$ in the flow tube, and measurements of $\mathrm{OH}$ reactivity using the flow tube method thus also require simultaneous measurements of ambient NO concentrations in order to correct for interferences from $\mathrm{HO}_{2}+\mathrm{NO}$, which can be quite significant. For example, for 75 ppb NO, a typical rush hour mixing ratio in Mexico City, a correction factor of $\sim 1.7$ was required to account for the production of $\mathrm{OH}$ from $\mathrm{HO}_{2}+\mathrm{NO}$ within the flow tube (Shirley et al., 2006).

In the comparative reactivity technique, a reactive molecule not usually present in air, typically pyrrole, is entrained in a gas flow and the rate of its decay owing to reaction with artificially high concentrations of $\mathrm{OH}$ is measured in "zero" air and ambient air by proton transfer quadrupole mass spectrometry (PTR-QMS) (Sinha et al., 2008), proton transfer time of flight mass spectrometry (PTR-ToFMS) (Michoud et al., 2015) or photoionisation detection (GC-PID) (Nölscher et al., 2012). Comparison of the rates of decay of the molecule in "zero" air and ambient air enables determination of the competition between the reaction of $\mathrm{OH}$ with the known concentration of the reactive molecule and the reaction of $\mathrm{OH}$ with sinks in ambient air, thus enabling measurement of the ambient $\mathrm{OH}$ reactivity. Absolute measurement of the physical loss rate of $\mathrm{OH}$ is not required for the technique, and the limit of detection of comparative reactivity instruments is determined by the sensitivity to changes in the signal corresponding to the concentration of the reactive species. However, $\mathrm{OH}$ radicals are typically produced in comparative reactivity instruments through Reactions (R1-R2), in a similar manner to that used in flow tube instruments and thus also producing high concentrations of $\mathrm{HO}_{2}$. Interferences resulting from $\mathrm{OH}$ production from $\mathrm{HO}_{2}+\mathrm{NO}$ are thus also potentially problematic for comparative reactivity instruments and knowledge of $\mathrm{NO}$ concentrations are required to correct for 
any interferences. In addition, the amount of $\mathrm{OH}$ produced is dependent on humidity, and it is essential to ensure constant humidity between measurements made in "zero" air and those made in ambient air, with significant corrections often necessary to account for any differences (Michoud et al., 2015).

The laser flash photolysis technique (Sadanaga et al., 2004a) produces $\mathrm{OH}$ in isolation (i.e. with no simultaneous production of $\mathrm{HO}_{2}$ ) via laser photolysis of $\mathrm{O}_{3}$, typically at a wavelength of $266 \mathrm{~nm}$, followed by reaction of $\mathrm{O}\left({ }^{1} \mathrm{D}\right)$ with ambient $\mathrm{H}_{2} \mathrm{O}$ (Reactions $\mathrm{R} 4-\mathrm{R} 5$ ):

$\mathrm{O}_{3}+\mathrm{h} v(\lambda=266 \mathrm{~nm}) \rightarrow \mathrm{O}_{2}+\mathrm{O}\left({ }^{1} \mathrm{D}\right)$

$\mathrm{O}\left({ }^{1} \mathrm{D}\right)+\mathrm{H}_{2} \mathrm{O} \rightarrow 2 \mathrm{OH}$.

The production of $\mathrm{OH}$ without initial co-production of $\mathrm{HO}_{2}$ minimises potential interferences from $\mathrm{HO}_{2}+\mathrm{NO}$ and renders the flash photolysis technique more suitable to high $\mathrm{NO}_{x}$ $\left(\mathrm{NO}_{x}=\mathrm{NO}+\mathrm{NO}_{2}\right)$ environments. The laser flash photolysis method also has the advantage that the production of $\mathrm{OH}$ radicals is uniform throughout the reaction cell, minimising the risk of poor mixing which is potentially problematic for the flow tube and comparative reactivity techniques. Flow rates of sampled air are typically lower for the laser flash photolysis instruments $\left(\sim 12-20\right.$ standard $\left.\mathrm{L} \mathrm{min}^{-1}\right)$ (Sadanaga et al., 2004a) than for those using flow tubes $(\sim 300$ 900 standard L min $^{-1}$ ) (Kovacs and Brune, 2001; Kovacs et al., 2003; Ingham et al., 2009; Hansen et al., 2014), and the resulting laminar flow of gas reduces contact of the gas with the walls of the instrument, thus reducing the physical loss rate of $\mathrm{OH}$ and associated uncertainties. Although averaging of data is often required to improve signal-to-noise, a significant advantage of the laser flash photolysis technique is the ability to measure ambient $\mathrm{OH}$ reactivity in "real-time" through time-resolved measurements of the $\mathrm{OH}$ decay following photolysis. The technique has the potential for significantly enhanced time resolution, both in terms of the number of time points obtained during the decay of $\mathrm{OH}$, and the averaging time over which the data are reported, compared to the flow tube or comparative reactivity methods.

The first atmospheric measurements of total $\mathrm{OH}$ reactivity were made at an urban background site in Nashville, TN, USA, in summer 1999 using the flow tube technique (Kovacs and Brune, 2001; Kovacs et al., 2003). Calculations of $\mathrm{OH}$ reactivity, using VOC measurements co-located with the reactivity measurements, underestimated the total observed reactivity by $\sim 30 \%$ on average owing to unmeasured or unknown VOCs and VOC oxidation products (Kovacs et al., 2003). Subsequent measurements at an urban background site in New York, NY, USA, were, on average, within $10 \%$ of the calculated reactivity in summer 2001 (Ren et al., 2003), but were underestimated by 30-40\% during morning and evening rush hours in winter (Ren et al., 2006a). Significant underestimation of the measured $\mathrm{OH}$ reactivity in the morning rush hour was also reported for observations in the Mexico City Metropolitan Area (MCMA), with the observed reactivity reaching $120 \mathrm{~s}^{-1}$ (Shirley et al., 2006). High $\mathrm{OH}$ reactivity has also been observed in Paris during the MEGAPOLI campaign in 2010, with $k_{\mathrm{OH}}$ reaching $130 \mathrm{~s}^{-1}$ for continental air masses and calculations based on measured VOC concentrations underestimating the reactivity by up to $75 \%$ (Dolgorouky et al., 2012). Reactivity measurements in Tokyo were underestimated in summer, spring and autumn, but reproduced to within $5 \%$ in winter, with the reactivity correlating well with $\mathrm{NO}_{x}$ throughout the year (Sadanaga et al., 2004b; Yoshino et al., 2006; Chatani et al., 2009; Yoshino et al., 2012). Aircraft measurements of $\mathrm{OH}$ reactivity have also shown that reactivity tends to decrease with altitude, with discrepancies between observed and calculated reactivity most pronounced at altitudes up to $2 \mathrm{~km}$ and tending towards agreement at altitudes above $4 \mathrm{~km}$ (Mao et al., 2009).

Flow tube measurements at an urban site in Houston, US, during the TEXAQS2000 and TRAMP2006 campaigns (Mao et al., 2010) and at a forested site at Whiteface Mountain, NY, USA (Ren et al., 2006b), were well reproduced by model calculations. However, measurements made at a coastal site in Norfolk, UK, typically characterised by relatively "clean" air were significantly underestimated and attributed to the presence of numerous high molecular mass VOCs at low concentrations which were not included in the VOC measurement suite (Lee et al., 2009; Ingham et al., 2009). The presence of unmeasured VOCs was also indicated for the PROPHET 2000 campaign at a forested site in Michigan, USA, during which the measured $\mathrm{OH}$ reactivity was underestimated by $\sim 50 \%$ on average, with the "missing" $\mathrm{OH}$ reactivity exhibiting a strong temperature dependence potentially resulting from temperature-dependent emissions of unmeasured biogenic VOCs (Di Carlo et al., 2004). Uncertainties in emissions and chemistry of biogenic VOCs, particularly in the oxidation chemistry of isoprene and its oxidation products, have also been responsible for underpredictions of observed $\mathrm{OH}$ reactivity in forested regions in Suriname (Sinha et al., 2008) and Borneo (Whalley et al., 2011; Edwards et al., 2013). Model calculations of OH reactivity in Borneo underestimated the observed diurnal mean reactivity by $30 \%$, and indicated that uncertainties in the chemistry and deposition rates of secondary oxidation products could potentially explain the observed reactivity without the need for additional primary VOC emissions, and that at least $50 \%$ of the carbon-containing compounds which react with $\mathrm{OH}$ were not measured (Edwards et al., 2013). Biogenic VOCs also dominated the daytime $\mathrm{OH}$ reactivity in the Pearl River Delta region, China, with isoprene and its oxidation products comprising $\sim 40 \%$ of the total $\mathrm{OH}$ reactivity in the afternoon and observed reactivity underestimated by $\sim 50 \%$ when calculated from measured $\mathrm{OH}$ sinks but reproduced by model calculations considering the contributions from secondary oxidation products (Lou et al., 2010). However, observations of $\mathrm{OH}$ reactivity in a forested region in Colorado, 
USA, during the BEACHON-SRM08 campaign were underestimated by model calculations $(\sim 30 \%)$, with the dominant VOCs found to be 2-methyl-3-buten-2-ol (MBO) and monoterpenes (Nakashima et al., 2014).

Using a branch enclosure technique, Kim et al. (2011) demonstrated that underestimations of observed $\mathrm{OH}$ reactivity at the PROPHET field site, Michigan, USA, during the 2009 CABINEX campaign were related to oxidation products of known and measured biogenic VOCs, rather than to unknown or unmeasured primary VOC emissions. Model calculations were able to reproduce the CABINEX OH reactivity observations below the forest canopy, but discrepancies were apparent above the canopy, indicating the presence of unmeasured trace gases above the forest canopy (Hansen et al., 2014). Model calculations and experiments using the comparative reactivity method at a forested site in Finland also observed differences between $\mathrm{OH}$ reactivity measured in the forest canopy and above the canopy (Mogensen et al., 2011; Nölscher et al., 2012). While the in-canopy reactivity was typically higher than the above-canopy reactivity, transport of wildfire plumes to the site significantly increased the above-canopy reactivity, increasing it above the in-canopy level and increasing the "missing" reactivity above the canopy from $58 \%$ for "normal" conditions to $73 \%$ for periods impacted by transported pollution (Nölscher et al., 2012).

$\mathrm{OH}$ reactivity measurements have also been used to determine ozone production rates in southwestern Spain during the DOMINO campaign (Sinha et al., 2012) and in London during the ClearfLo campaign (Whalley et al., 2016), and have been used in laboratory studies to assess our understanding of combustion systems (Nakashima et al., 2010) and atmospheric isoprene oxidation mechanisms (Nakashima et al., 2012; Nölscher et al., 2014).

Measurements of $\mathrm{OH}$ reactivity thus have a number of applications, and can be used to improve our understanding of atmospheric composition and chemistry. In this work we present the design and characterisation of an instrument using laser flash photolysis coupled with laser-induced fluorescence (LFP-LIF) to measure $\mathrm{OH}$ reactivity in the field and in chamber experiments.

\section{Experimental}

A schematic of the $\mathrm{OH}$ reactivity instrument is given in Fig. 1. The instrument comprises a reaction cell (described in Sect. 2.1) and a detection cell (described in Sect. 2.2), with the two cells typically situated approximately $5 \mathrm{~m}$ above ground level on the roof of a shipping container housing the FAGE (fluorescence assay by gas expansion) mobile laboratory during ambient measurements. During laboratory and chamber measurements, the instrument is configured within the laboratory. Thus, for ambient measurements, and laboratory and chamber measurements made at room temperature, the temperature in the $\mathrm{OH}$ reactivity instrument is the same as the source of the air being sampled.

\subsection{Reaction cell}

The reaction cell consists of a cylindrical stainless steel tube of $50 \mathrm{~mm}$ internal diameter and $85 \mathrm{~cm}$ in length. Ambient air is drawn through a stainless steel sampling line $(50 \mathrm{~mm}$ internal diameter and $20 \mathrm{~cm}$ in length), enters the reaction cell at $90^{\circ}$ to the air flow in the tube, and is drawn along the tube by an extractor fan (612F, DC Axial Fan, EBM-Papst) mounted on the exit arm situated immediately prior to the $\mathrm{OH}$ detection cell (Sect. 2.2), as shown in Fig. 1. More recently, the connection between the reaction cell and the exhaust has been replaced with an exhaust that draws air out of the cell over the full circumference of the cell. Although the data recorded with the new exhaust are not reported in this paper, we do not see any significant change in results between the different exhaust designs, but this will be discussed in future publications.

The fan speed determines the flow rate of gas in the reaction cell, and is set to ensure a laminar flow of air through the cell with a Reynold's number less than 2300 . The flow rate of gas, determined by measurement of the flow velocity using a hot-wire anemometer (TSI Air velocity transducer 8455-150) or set by calibrated mass flow controllers during laboratory experiments (Sects. 4, 6, and 7) and measurements of instrument zeroes (Sect. 3.1), is in the range 12 to 14 standard $\mathrm{L} \mathrm{min}^{-1}$, giving a residence time of 7 to $8 \mathrm{~s}$ in the reaction cell and a Reynold's number of $\sim 360$, which is below that required for laminar flow.

Production of $\mathrm{OH}$ radicals within the reaction cell is achieved by the $266 \mathrm{~nm}$ laser photolysis of $\mathrm{O}_{3}$ in the presence of water vapour (Reactions R4-R5). A flashlamp pumped Nd: YAG laser (Big Sky Laser CFR 200, Quantel USA) is used to generate laser light at $1064 \mathrm{~nm}$, which is frequency doubled to $532 \mathrm{~nm}$ (lithium triborate, $\mathrm{LiB}_{3} \mathrm{O}_{5}$, doubling crystal) and then frequency doubled to generate the fourth harmonic $266 \mathrm{~nm}$ radiation (caesium lithium triborate, $\mathrm{CsLiB}_{6} \mathrm{O}_{10}$, doubling crystal) with pulse energies of $\sim 50 \mathrm{~mJ}$, pulse length $8 \mathrm{~ns}$, and beam diameter of $6.35 \mathrm{~mm}$. The pulse repetition frequency is typically $1 \mathrm{~Hz}$, and has been varied in experiments between 0.1 and $1 \mathrm{~Hz}$ with no significant impact observed. The laser is operated with a $Q$-switch to modulate the intracavity losses and maximise the pulse energy.

The $266 \mathrm{~nm}$ laser head is situated adjacent to the reaction cell in order to minimise the footprint of the instrument when used in the field. The laser head is powered, controlled and water cooled by an Integrated Cooler and Electronics unit (Big Sky Laser ICE450, Quantel USA) which is housed within the FAGE shipping container and powered via an uninterruptible power supply (APC 1000VA, American Power Conversion by Schneider Electric). 


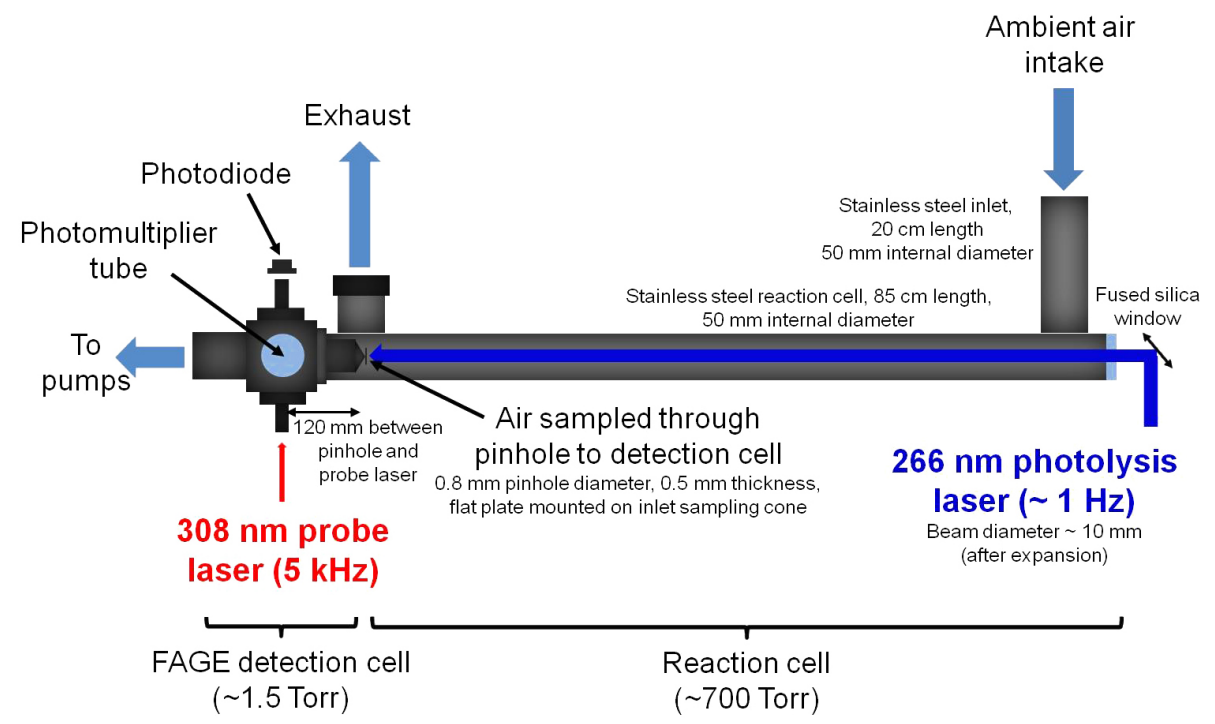

Figure 1. Schematic of the laser flash photolysis laser-induced fluorescence $\mathrm{OH}$ reactivity instrument for experiments and field measurements in which the FAGE detection cell was situated at the end of the reaction cell and sampled from the centre of the photolysed volume, leading to $\mathrm{OH}$ decays described by a single exponential. All laboratory and field measurements shown in this work were obtained with the instrument configuration as shown here. See text for further details.

Laser light exiting the laser head is directed into the reaction cell using two dielectrically coated $266 \mathrm{~nm}$ turning mirrors of $1^{\prime \prime}$ diameter (Thorlabs, NB1-K04). Immediately prior to the reaction cell, the $266 \mathrm{~nm}$ beam is expanded to a diameter of $\sim 10 \mathrm{~mm}$ by a telescope incorporating a plano-concave lens (Thorlabs LC4252, focal length $=-30 \mathrm{~mm}$ ) and a plano-convex lens (Thorlabs LA4148, focal length $=50 \mathrm{~mm}$ ) housed in a lens tube (SM1M20, Thorlabs) to increase the photolysis volume within the reaction cell. The photolysis laser enters the reaction cell through a fused silica window, initiating $\mathrm{OH}$ radical production.

Typically, there is sufficient production of $\mathrm{OH}$ in the instrument from Reactions (R4-R5) at ambient concentrations of $\mathrm{O}_{3}$ and water vapour in order to measure a temporal decay of $\mathrm{OH}$. At low ambient concentrations of $\mathrm{O}_{3}(<10 \mathrm{ppb})$ or during laboratory tests (Sects. 4, 6 and 7) and measurement of instrument zeroes (Sect. 3), the $\mathrm{OH}$ radical concentration in the reaction cell is increased by passing a small flow ( 0.5 standard $\mathrm{L} \mathrm{min}^{-1}$ ) of humidified ultra-high purity air (BTCA 178, BOC Special Gases) across a low pressure $\mathrm{Hg}$ vapour lamp and mixed with the main sampled air flow (12-14 standard $\mathrm{L} \mathrm{min}^{-1}$ ) in the inlet to the reaction cell. The mixing ratio of ozone in the reaction cell is increased by $\sim 50 \mathrm{ppb}$ by this method (measured by an ozone analyser (Thermo Environmental Instruments Inc., $49 \mathrm{C} \mathrm{O}_{3}$ Analyser) situated at the end of the reaction cell during laboratory tests). Given knowledge of the rate coefficient for reaction of $\mathrm{OH}$ with $\mathrm{O}_{3}\left(k_{\mathrm{OH}}+\mathrm{O}_{3}=7.3 \times 10^{-14} \mathrm{~cm}^{3} \mathrm{~s}^{-1}\right.$, Atkinson et al., 2004), the chemical loss of $\mathrm{OH}$ resulting from the addition of $50 \mathrm{ppb} \mathrm{O}_{3}$ is $<0.1 \mathrm{~s}^{-1}$ at $298 \mathrm{~K}$, and any loss of VOCs in the reaction cell through reaction with ozone is extremely small given the reaction times involved.

\subsection{OH detection cell}

$\mathrm{OH}$ radicals in the reaction cell are monitored by laserinduced fluorescence (LIF) using the FAGE technique. The LIF-FAGE detection cell has been described previously in detail (Ingham et al., 2009), thus only a brief description will be given here.

Initial experiments were conducted with the detection cell situated midway along the reaction cell, and sampling at $90^{\circ}$ to the direction of air flow along the reaction cell, in a similar design to that described by Sadanaga et al. (2004a) and Lou et al. (2010). However, the observed $\mathrm{OH}$ decays in such a configuration displayed biexponential behaviour, comprising a fast initial decay followed by a slower decay representative of the expected $\mathrm{OH}$ reactivity, as observed in previously described instruments (Sadanaga et al., 2004a; Lou et al., 2010). In this configuration, the photolysis laser is aligned such that the beam passes across the inlet to the detection cell without hitting the inlet. The air sampled in to the detection cell thus likely contains air that has experienced the photolysis laser (containing elevated $\mathrm{OH}$ concentrations) and air that has not experienced the photolysis laser (which will have significantly lower or zero $\mathrm{OH}$ concentrations), with this mixing of air potentially leading to an apparent increase in the initial $\mathrm{OH}$ decay rate owing to dilution of the air containing elevated $\mathrm{OH}$ concentrations with air containing lower (or zero) concentrations. Once mixing of the air having experienced the photolysis laser with that outside the beam diameter has 
occurred sufficiently to give uniform $\mathrm{OH}$ concentrations in the reaction cell the observed $\mathrm{OH}$ decay will result from the chemical losses in the instrument, leading to biexponential decays. Such biexponential behaviour has been attributed to similar effects of non-homogeneous spatial distributions of $\mathrm{OH}$ near the inlet to the detection cell (Lou et al., 2010) and to local heating and turbulence of the gas flow caused by the photolysis laser (Sadanaga et al., 2004a). A comparison between sampling at $90^{\circ}$ to the direction of air flow along the reaction cell and sampling along the axis of the direction of air flow from the centre of the reaction cell has been reported previously (Amedro et al., 2012), with different fitting procedures required to extract the $\mathrm{OH}$ reactivity for the different instrument configurations attributed to differences in physical effects such as diffusion which were more significant when sampling at $90^{\circ}$ (Amedro et al., 2012).

Subsequent experiments in this work (including all those described below) were performed with the detection cell situated at the end of the reaction cell along the same axis as the direction of air flow to sample air directly from the centre of the reaction cell. This configuration reduces the chance of sampling air into the detection cell that has not experienced the photolysis laser beam, and thus reduces the impact of physical effects such as diffusion. The observed $\mathrm{OH}$ signals in this instrument configuration are described by a single exponential decay, although biexponential decays can still be obtained if the photolysis laser is not correctly aligned along the axis of the reaction cell.

Air is sampled from the centre of the reaction cell through a pinhole of $0.8 \mathrm{~mm}$ diameter and $0.5 \mathrm{~mm}$ thickness into the aluminium detection cell, which consists of three orthogonal axes and is black anodised to minimise light scattering within the cell. The pressure in the cell is measured by a capacitance manometer (Sensotec Z/606-01ZA) and is maintained at $\sim 1.5$ Torr by a roots blower backed by a rotary pump (Leybold Vacuum SV200/WAU1001), resulting in an air flow of approximately 4 standard $\mathrm{L} \mathrm{min}^{-1}$ and a supersonic expansion of the air as it is drawn through the pinhole.

The probe laser consists of a Nd:YAG pumped Ti:sapphire laser (Photonics Industries) which generates broadband radiation in the range $690-1000 \mathrm{~nm}$. A diffraction grating is used to select radiation with $\lambda=924 \mathrm{~nm}$, which is frequency tripled through generation of the second harmonic at $462 \mathrm{~nm}$ followed by sum-frequency mixing of the $462 \mathrm{~nm}$ radiation with that at $924 \mathrm{~nm}$ to produce the $308 \mathrm{~nm}$ light with a pulse repetition frequency (PRF) of $5 \mathrm{kHz}$, pulse length (full width half maximum (FWHM)) of $35 \mathrm{~ns}$, laser line width (FWHM) of $0.065 \mathrm{~cm}^{-1}$ and beam diameter of $\sim 3 \mathrm{~mm}$ (Bloss et al., 2003).

A reference fluorescence cell, containing a heated nichrome wire filament and humidified air at $\sim 2$ Torr to produce a constant stable source of $\mathrm{OH}$ radicals from dissociation of water vapour, is used to facilitate tuning the probe laser to the precise wavelength required for the desired $\mathrm{OH}$ transition. Approximately $1 \mathrm{~mW}$ of the $308 \mathrm{~nm}$ laser light is used for this purpose, with $\sim 9 \mathrm{~mW}$ used to make measurements of $\mathrm{OH}$ reactivity and a further $\sim 13 \mathrm{~mW}$ remaining to make measurements of ambient $\mathrm{OH}, \mathrm{HO}_{2}$ and $\mathrm{RO}_{2}$ concentrations in a separate instrument (see, for example, Whalley et al., 2016).

The probe laser, reference cell and pumps are all situated inside the shipping container. The $\sim 9 \mathrm{~mW}$ of the $308 \mathrm{~nm}$ laser light used to measure $\mathrm{OH}$ reactivity is passed to the detection cell on the roof of the shipping container via an antireflective coated optical fibre with an angled and polished end (Oz Optics, QMMJ-55-UVVIS-200/240-3-30-AR2-SP, length $=30 \mathrm{~m}$ ) through a baffled side-arm at $90^{\circ}$ to the air flow. The probe laser light exits the detection cell through a baffled side-arm and is directed onto a photodiode (New Focus Large Area Photoreceiver 2032) to measure the laser power to enable normalisation of fluorescence signals for fluctuations in laser power. For a recent intercomparison at the SAPHIR chamber, the $\mathrm{OH}$ reactivity instrument, comprising the reactor flowtube and $\mathrm{OH}$ fluorescence and associated equipment was placed in the shipping container itself.

Fluorescence from electronically excited $\mathrm{OH}$ radicals resulting from excitation of the $Q_{1}(1) A^{2} \Sigma^{+}\left(v^{\prime}=0\right)-$ $\mathrm{X}^{2} \Pi_{3 / 2}\left(v^{\prime \prime}=0\right)$ transition at $308 \mathrm{~nm}$ is collimated by a symmetrical biconvex collimating lens (Melles-Griot, focal length $=50 \mathrm{~mm}$ at $\lambda=546.1 \mathrm{~nm}$, diameter $=50 \mathrm{~mm}$ ) and focused onto the photocathode of a channeltron photomultiplier tube (PMT) (Perkin Elmer C 943P) by two plano-convex focusing lenses (UQG Optics Ltd., focal length $=75 \mathrm{~mm}$ at $\lambda=250 \mathrm{~nm}$, diameter $=50 \mathrm{~mm}$ ). A narrow band UV interference filter (Barr Associates Inc., FWHM bandwidth of $8 \pm 1.6 \mathrm{~nm}$ centred at $309 \pm 1 \mathrm{~nm}$ with a peak transmission of $>50 \%$ at $308 \mathrm{~nm}$ and a blocking factor of $10^{6}$ at other wavelengths) is situated between the excitation region in the detection cell and the PMT to minimise detection of scattered solar photons. The solid angle from which fluorescence is collected is effectively doubled through the use of a spherical concave mirror coated for high UV reflectance which is mounted in the detection cell opposite the side-arm bearing the PMT. Discrete photon signals on the PMT are processed using a multi-channel scaler photon counting card (Becker and Hickl, PMS 400, minimum bin width of $250 \mathrm{~ns}$ ) in the computer used to control the instrument.

\subsection{Instrument control}

A digital delay pulse generator (Stanford Research Systems DG535) produces a $5 \mathrm{kHz}$ TTL (transistor-transistor logic) pulse to trigger the Ti:sapphire laser and a second delay generator (Stanford Research Systems DG535) which subsequently triggers the gating of the PMT detector for the reactivity instrument and a third digital delay pulse generator (Berkeley Nucleonics Corporation 555) to trigger the $266 \mathrm{~nm}$ photolysis laser and the photon counting card at the specified pulse repetition frequency in synchronisation with the 
$308 \mathrm{~nm}$ probe laser. A personal computer is used to automate data collection, with analogue signals from measurements of the pressure in the detection cell and the power of the $308 \mathrm{~nm}$ probe laser at the photodiode attached to the detection cell digitised by an $A / D$ card (Measurement Computing, PCIDAS 1200). Electrical power to all parts of the instrument is supplied via an uninterruptible power supply (APC 1000VA).

\subsection{Data acquisition}

Data acquisition is initiated by triggering of the photon counting card, with a background signal measured for $100 \mathrm{~ms}$ before triggering of the $266 \mathrm{~nm}$ photolysis laser and production of $\mathrm{OH}$ in the reaction cell. To avoid saturation of the PMT resulting from detection of the $308 \mathrm{~nm}$ laser pulse itself, the PMT is gated off at the onset of the $308 \mathrm{~nm}$ laser pulse ( $35 \mathrm{~ns}$ FWHM) until $\sim 100 \mathrm{~ns}$ after the laser pulse, thereby preventing detection of any reflected or scattered laser light. The fluorescence signal is typically collected for $1 \mu \mathrm{s}$ following each $308 \mathrm{~nm}$ probe laser pulse. Repeated measurements of the $\mathrm{OH}$ fluorescence signal are taken for $900 \mathrm{~ms}$ following each $266 \mathrm{~nm}$ photolysis laser pulse, during which time the $\mathrm{OH}$ concentration and hence the fluorescence signal will decay to the background level. Under normal conditions this occurs within $\sim 300 \mathrm{~ms}$ of the photolysis laser pulse, although this is of course dependent upon the magnitude of the $\mathrm{OH}$ reactivity, and may be longer. The pulse repetition frequency of the $308 \mathrm{~nm}$ probe laser $(5 \mathrm{kHz})$ results in measurement of the $\mathrm{OH}$ fluorescence signal every $200 \mu \mathrm{s}$ throughout the measurement period. The data collection cycle, as illustrated in Fig. 2 is typically repeated every $1 \mathrm{~s}$ (i.e. with the photolysis laser having a pulse repetition frequency of $1 \mathrm{~Hz}$ ). Experiments, both in the laboratory and in the field, in which the PRF of the photolysis laser was varied between 0.1 and $1 \mathrm{~Hz}$ showed no effect on the observed $\mathrm{OH}$ reactivity (Sect. 8).

When measurements of $\mathrm{OH}$ reactivity are made alongside those of ambient $\mathrm{OH}$ concentrations, the acquisition of $\mathrm{OH}$ reactivity data is linked to measurements of ambient $\mathrm{OH}$ concentrations owing to the dual use of the $308 \mathrm{~nm}$ excitation laser. Under such circumstances, measurements are taken on an approximate $7 \mathrm{~min}$ cycle, with a $5 \mathrm{~min}$ "online" period during which the $308 \mathrm{~nm}$ laser is at the precise wavelength to excite the $\mathrm{OH}$ transition, followed by a 1 min "offline" period during which the wavelength of the laser is moved to a nearby wavelength at which the $\mathrm{OH}$ transition is not excited in order to enable measurement of a background signal for determination of ambient $\mathrm{OH}$ concentrations (see, for example, Whalley et al. 2010). Approximately $1 \mathrm{~min}$ is then required to scan the laser wavelength over the $\mathrm{OH}$ transition to find the maximum $\mathrm{OH}$ fluorescence signal in the reference cell (Sect. 2.2). $\mathrm{OH}$ reactivity measurements are thus taken during the $5 \mathrm{~min}$ online period, and data from successive measurement cycles during each online period are co-added to improve the signal-to-noise ratio. Figure 3 shows typical $\mathrm{OH}$ decays de-
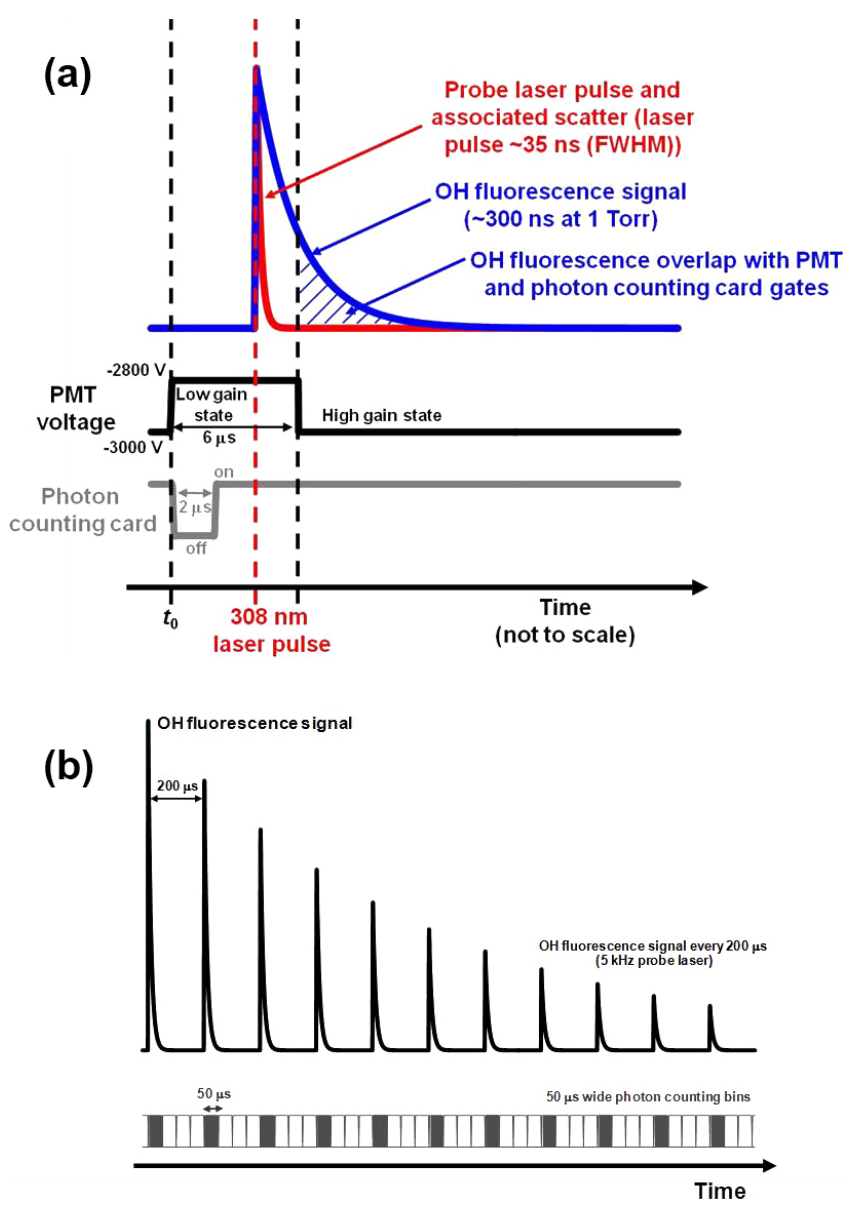

Figure 2. (a) Schematic to illustrate the Stanford Research Systems delay generator controlled gate timing of the PMT detector and photon counting card in the $\mathrm{OH}$ reactivity instrument. The blue hatched region indicates the overlap between the $\mathrm{OH}$ fluorescence signal and the photon counting gates; (b) Schematic to illustrate the photon counting bin structure used to collect $\mathrm{OH}$ fluorescence photons after each $308 \mathrm{~nm}$ probe laser pulse $(5 \mathrm{kHz}$ pulse repetition frequency). Four $50 \mu$ s wide photon counting bins cover the time period between each $308 \mathrm{~nm}$ laser pulse, but only the bins immediately after the laser pulse collect any fluorescence photons (shaded bins), and only the photon counts from these bins are used to construct the $\mathrm{OH}$ decay.

rived from the co-addition of data recorded throughout $5 \mathrm{~min}$ online periods during the Clean Air for London (ClearfLo) campaign in summer 2012.

Measurements of $\mathrm{OH}$ reactivity may also be made independently of any other use of the $308 \mathrm{~nm}$ probe laser, in which case the timescale over which successive measurement cycles are co-added may be selected as desired, with the laser periodically scanned over the $\mathrm{OH}$ transition to ensure that the maximum $\mathrm{OH}$ signal is obtained. 

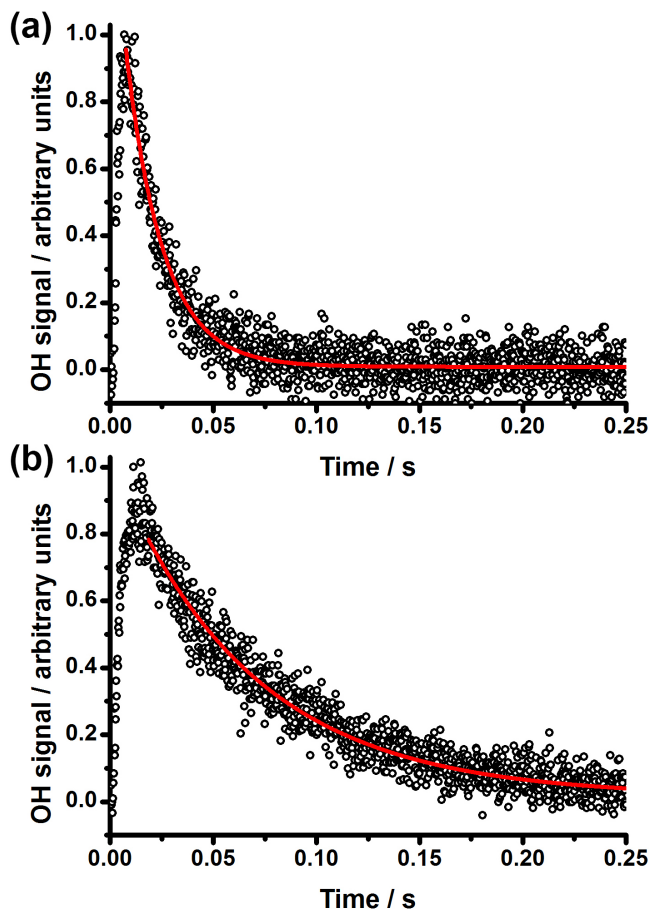

Figure 3. Typical $\mathrm{OH}$ time profiles following photolysis of ambient air (mixed with a small flow of $\mathrm{N}_{2} / \mathrm{O}_{2} / \mathrm{O}_{3} / \mathrm{H}_{2} \mathrm{O}$ ) observed during the Clean Air for London (ClearfLo) campaign (black points) with fits of Eq. (5) (red lines) to the LIF data to determine $k_{\mathrm{OH}}^{\prime}$ for data recorded (a) during a polluted period on 25 July 2012 $\left(k_{\mathrm{OH}}^{\prime}=(46.6 \pm 3.2) \mathrm{s}^{-1}\right)$ and (b) during a cleaner period on $7 \mathrm{Au}-$ gust $2012\left(k_{\mathrm{OH}}^{\prime}=(13.9 \pm 0.9) \mathrm{s}^{-1}\right)$. Time zero is defined as the time at which photolysis occurs. Decays represent data co-added throughout 5 min periods.

\subsection{Calibration of the FAGE detection cell}

Calibration of the detection cell, although not strictly necessary for measurements of $\mathrm{OH}$ reactivity, is required to ensure that pseudo-first-order conditions are met in the reaction cell (i.e. combined concentrations of $\mathrm{OH}$ sinks are in excess over the $\mathrm{OH}$ concentration) and provides a means to determine any potential interferences from production of $\mathrm{OH}$ via ambient $\mathrm{HO}_{2}+\mathrm{NO}$ in the reaction cell (from ambient $\mathrm{HO}_{2}$ which may survive the sampling inlet, and any $\mathrm{HO}_{2}$ generated following oxidation of $\mathrm{OH}$ sinks in the instrument) and to monitor potential changes in instrument sensitivity with time.

The calibration procedure has been described in detail by Commane et al. (2010). Production of $\mathrm{OH}$ (and $\mathrm{HO}_{2}$ ) is achieved through Reaction (R1) (and $\mathrm{HO}_{2}$ through Reaction R2) by passing a turbulent flow of humidified ultra-high purity air (BTCA 178, BOC Special Gases) across a low pressure mercury vapour lamp to photolyse water vapour at $\lambda=184.9 \mathrm{~nm}$.

$\mathrm{H}_{2} \mathrm{O}+\mathrm{h} v(\lambda=184.9 \mathrm{~nm}) \rightarrow \mathrm{H}+\mathrm{OH}$
The concentration of $\mathrm{OH}$ is given by Eq. (4):

$[\mathrm{OH}]=\left[\mathrm{H}_{2} \mathrm{O}\right] \sigma_{\mathrm{H}_{2} \mathrm{O}} \varphi_{\mathrm{OH}} \mathrm{F} \delta \mathrm{t}$,

where $\sigma_{\mathrm{H}_{2} \mathrm{O}}$ is the absorption cross-section of $\mathrm{H}_{2} \mathrm{O}$ at $184.9 \mathrm{~nm}(7.1 \pm 0.2) \times 10^{-20} \mathrm{~cm}^{2}$ (Cantrell et al., 1997; Creasey et al., 2000), $\varphi_{\mathrm{OH}}$ is the quantum yield for $\mathrm{OH}$ production $\left(\varphi_{\mathrm{OH}}=1\right), F$ is the photon flux of the mercury lamp at $184.9 \mathrm{~nm}$ and $\delta t$ is the residence time in the photolysis region. The product $F \delta t$ is determined by $\mathrm{N}_{2} \mathrm{O}$ actinometry (Commane et al., 2010), with $F$ varied by changing the current supplied to the lamp, and $\delta t$ controlled by the flow rate of the gas used in the calibration. The concentration of water vapour in the flow is determined by diverting a small known flow of the air to a dew point hygrometer (CR4, Buck Research Instruments), and was varied between 300 and $10000 \mathrm{ppm}$ during calibration experiments.

The calibration for $\mathrm{OH}$ was conducted over a range of mercury lamp fluxes and water vapour mixing ratios (between 300 and $10000 \mathrm{ppm})$, giving a calibration factor $\left(C_{\mathrm{OH}}\right)$ of $(2.13 \pm 0.27) \times 10^{-8}$ counts s${ }^{-1}$ molecule ${ }^{-1} \mathrm{~cm}^{3} \mathrm{~mW}^{-1}$. The $1 \sigma$ instrumental limit of detection for $\mathrm{OH}$ radicals was determined to be $\sim 10^{7} \mathrm{~cm}^{-3}$ for a $5 \mathrm{~min}$ integration period, enabling observation of sufficient changes in $\mathrm{OH}$ radical concentrations in the reaction cell to allow measurements of ambient $\mathrm{OH}$ reactivity.

For a minimum ambient $\mathrm{O}_{3}$ mixing ratio of $10 \mathrm{ppb}$ (below which $\sim 50 \mathrm{ppb}$ is added to the instrument (Sect. 2.1), an absorption cross-section for $\mathrm{O}_{3}$ of $9.65 \times 10^{-18} \mathrm{~cm}^{2}$ at $266 \mathrm{~nm}$ (Atkinson et al., 2004), typical laser fluence of $\sim 50 \mathrm{~mJ} \mathrm{~cm}^{-2}$ and a quantum yield of 0.9 for production of $\mathrm{O}\left({ }^{1} \mathrm{D}\right)$ (Matsumi et al., 2002), the initial $\mathrm{O}\left({ }^{1} \mathrm{D}\right)$ number density following photolysis is $\sim 1.6 \times 10^{11} \mathrm{~cm}^{-3}$. For a water vapour concentration of $5 \times 10^{17} \mathrm{~cm}^{-3}(\sim 2 \%)$, competition between reaction of $\mathrm{O}\left({ }^{1} \mathrm{D}\right)$ with water $\left(k_{\mathrm{O} 1 \mathrm{D}}+\mathrm{H}_{2} \mathrm{O}=2.1 \times 10^{-10} \mathrm{~cm}^{3} \mathrm{~s}^{-1}\right.$, Atkinson et al., 2004), leading to $2 \mathrm{OH}$, and quenching of $\mathrm{O}\left({ }^{1} \mathrm{D}\right)$ by $\mathrm{N}_{2}\left(k_{\mathrm{O} 1 \mathrm{D}+\mathrm{N}_{2}}=3.1 \times 10^{-11} \mathrm{~cm}^{3} \mathrm{~s}^{-1}\right.$, Atkinson et al., 2004) or $\mathrm{O}_{2}\left(k_{\mathrm{O} 1 \mathrm{D}}+\mathrm{O}_{2}=4.0 \times 10^{-11} \mathrm{~cm}^{3} \mathrm{~s}^{-1}\right.$, Atkinson et al., 2004), to produce $\mathrm{O}\left({ }^{3} \mathrm{P}\right)$, typically leads to an initial $\mathrm{OH}$ concentration in the reactivity instrument of $>3 \times 10^{10} \mathrm{~cm}^{-3}$, in agreement with the calibration results. At higher ambient mixing ratios of $\mathrm{O}_{3}$, the initial $\mathrm{OH}$ concentration in the reactivity is increased, whilst maintaining pseudo-first-order conditions for $\mathrm{OH}$. For example, an ambient $\mathrm{O}_{3}$ mixing ratio of $100 \mathrm{ppb}$, as observed in some polluted environments, would be expected to generate $>3 \times 10^{11} \mathrm{~cm}^{-3} \mathrm{OH}$ (at $2 \%$ humidity), leading to improvements in the signal-to-noise ratio and minimisation of any potential interferences in measurements of $\mathrm{OH}$ reactivity (Sect. 6). 


\section{Determination of $\mathrm{OH}$ reactivity}

The observed pseudo-first-order rate coefficient for $\mathrm{OH}$ loss ( $\left.k_{\text {loss }}\right)$ is determined by least-squares fitting Eq. (5) to the time-resolved $\mathrm{OH}$ decay:

$S_{\mathrm{OH}, \mathrm{t}}=S_{\mathrm{OH}, 0} \exp \left(-k_{\mathrm{loss}} t\right)+b$,

where $S_{\mathrm{OH}, \mathrm{t}}$ is the fluorescence signal at time $t$ after firing of the $266 \mathrm{~nm}$ photolysis laser, $S_{\mathrm{OH}, 0}$ is the fluorescence signal at time zero (i.e. immediately following firing of the $266 \mathrm{~nm}$ laser and production of $\mathrm{OH}$ in the reaction cell), $k_{\text {loss }}$ is the observed rate coefficient for loss of the fluorescence signal, $t$ is the time since firing of the $266 \mathrm{~nm}$ photolysis laser and $b$ is the background fluorescence signal measured by the PMT averaged for the $100 \mathrm{~ms}$ prior to firing of the photolysis laser (typically zero). Fits are typically started within $5 \mathrm{~ms}$ of the peak in the $\mathrm{OH}$ signal, and data are fitted until the $\mathrm{OH}$ signal is essentially back to the background level by the end of the fit. Values for $S_{\mathrm{OH}, 0}$ and $k_{\text {loss }}$ are permitted to vary in the fitting process. Since the $\mathrm{OH}$ decays are well described by first-order kinetics, the fitted values for $S_{\mathrm{OH}, 0}$ and $k_{\text {loss }}$ do not depend in any way on the time period over which the decays are fitted. Figure 3 shows typical fits of Eq. (5) to measurements of $\mathrm{OH}$ reactivity made in ambient air.

The value for $k_{\text {loss }}$ determined from the fit contains a contribution from $k_{\mathrm{OH}, \mathrm{obs}}^{\prime}$, the rate coefficient for $\mathrm{OH}$ loss owing to chemical losses of $\mathrm{OH}$ in the reaction cell (the $\mathrm{OH}$ reactivity), and $k_{\text {phys }}$, the instrument "zero" corresponding to the rate coefficient for physical losses of $\mathrm{OH}$ owing to diffusion out of the sampling volume and heterogeneous losses on the walls on the reaction cell. The chemical loss of $\mathrm{OH}$ in the reaction cell is thus given by Eq. (6), and in order to determine the $\mathrm{OH}$ reactivity from measurements of $k_{\text {loss }}$ it is therefore essential to characterise $k_{\text {phys }}$ (Sect. 3.1).

$k_{\mathrm{OH}, \mathrm{obs}}^{\prime}=k_{\text {loss }}-k_{\mathrm{phys}}$

At low ambient concentrations of ozone $(<10 \mathrm{ppb})$ and in laboratory experiments (Sects. 4, 6 and 7) and measurements of $k_{\text {phys }}$, it was necessary to add a small flow of humidified air containing a constant mixing ratio of ozone $(\sim 50 \mathrm{ppb})$ to the main air flow sampled in order to produce sufficient $\mathrm{OH}$ radicals in the reaction cell. This "non-ambient" ozone added to the reaction cell results in a small loss of $\mathrm{OH}$ owing to the reaction of $\mathrm{O}_{3}$ with $\mathrm{OH}$, but is expected to be $<0.1 \mathrm{~s}^{-1}$ at $298 \mathrm{~K}$ (Sect. 2.1). However, addition of the small ozone-containing air flow $\left(0.5\right.$ standard $\left.\mathrm{L} \mathrm{min}^{-1}\right)$ to the sampled flow of ambient air ( 12 standard $\mathrm{L} \mathrm{min}^{-1}$ ) does require a correction for the dilution of the ambient air flow, such that the $\mathrm{OH}$ reactivity $\left(k_{\mathrm{OH}}^{\prime}\right)$ is given by Eq. (7):

$k_{\mathrm{OH}}^{\prime}=k_{\mathrm{OH}, \mathrm{obs}}^{\prime}(1+f)$,

where $f$ is the dilution factor of the ambient air flow, given by the ratio of the small ozone-containing flow rate to the total flow rate of the air in the reaction cell $(\sim 0.04$ for the conditions used in this work). Potential errors arising from errors in measurements of $k_{\text {phys }}$ and $f$ have been included in overall reported errors for $k_{\mathrm{OH}}^{\prime}$, and contribute, on average, 70 and $25 \%$, respectively, to the total uncertainty in $k_{\mathrm{OH}}^{\prime}$.

\subsection{Determination of $\boldsymbol{k}_{\text {phys }}$}

Determination of $k_{\text {phys }}$ is critical to the evaluation of the true $\mathrm{OH}$ reactivity from observations of the total $\mathrm{OH}$ loss rate in the instrument (Eqs. 7 and 8), and requires the measurement of the $\mathrm{OH}$ loss rate in the absence of any chemical removal processes such that $k_{\text {loss }}$ is equal to $k_{\text {phys }}$. A single value for $k_{\text {phys }}$ is determined (from several experiments) independently of any measurements of $k_{\mathrm{obs}}$, and is fitted over as much of the observed $\mathrm{OH}$ decay as possible using the procedure described above in order to obtain the best possible determination of $k_{\text {phys }}$ since fitting $k_{\text {phys }}$ over as much of the decay as possible reduces the uncertainty in the fit. As described above, determinations of $k_{\text {phys }}$ (and $k_{\text {obs }}$ ) are independent of the time period over which the data are fitted since the observed $\mathrm{OH}$ decays follow first-order kinetics and can be described with a single exponential function.

To minimise the chemical losses of $\mathrm{OH}$ in the reaction cell (and thus to minimise $k_{\mathrm{OH}, \mathrm{obs}}^{\prime}$ ) the loss of $\mathrm{OH}$ in the instrument is measured in ultra-high purity air (BTCA 178, BOC Special Gases) passed through scrubbers (Gatekeeper Gas Purifiers) to remove $\mathrm{H}_{2}, \mathrm{CO}$ and $\mathrm{CO}_{2}$ to sub-ppb levels. Despite the use of scrubbed ultra-high purity air, low levels of residual VOCs can remain in the air, leading to chemical losses. Such residual VOCs in the scrubbed ultra-high purity air have been quantified by gas-chromatography and their contributions $\left(<1 \mathrm{~s}^{-1}\right)$ to the observed $\mathrm{OH}$ loss subtracted.

Furthermore, humidification and addition of a small amount of $\mathrm{O}_{3}$ to the ultra-high purity air are necessary for the production of $\mathrm{OH}$ in the instrument during experiments to determine $k_{\text {phys }}$. Approximately $50 \mathrm{ppb}$ of $\mathrm{O}_{3}$ is added to ensure production of sufficient $\mathrm{OH}$, leading to a chemical loss of $<0.1 \mathrm{~s}^{-1}$ at $298 \mathrm{~K}$ through the reaction of $\mathrm{OH}$ with $\mathrm{O}_{3}$. Moreover, despite the use of purified water for humidification, obtained using a water purification system (PURELAB flex PRIPLB0163, Elga LabWater, Veolia Water Solutions \& Technologies), impurities in the water can lead to significant chemical losses for $\mathrm{OH}$ and the components in the purification system must remain uncontaminated in order to ensure accurate determinations of $k_{\text {phys }}$.

Determination of $k_{\text {phys }}$ in the laboratory and in the field for the ClearfLo campaign in London in 2012 gave an average value $(1.1 \pm 1.0) \mathrm{s}^{-1}$ (precision of $0.4 \mathrm{~s}^{-1}$ ) and $(1.25 \pm 0.42) \mathrm{s}^{-1}$ (precision of $0.2 \mathrm{~s}^{-1}$ ) for the campaign in York in 2014 (Sect. 7). 


\section{Instrumental validation via measurements of $k_{\mathrm{OH}}+\mathrm{CO}$ and $k_{\mathrm{OH}}+\mathrm{CH} 4$}

As a real-time technique, the accuracy of the time axis during which the $\mathrm{OH}$ decay is obtained is determined by the accuracy of the delay generators used to trigger the lasers and other delays (as described in Sect. 2.4 and shown in Fig. 2), which should be absolute within 1 ps. Hence the method should be absolute in terms of the time separation between points in the decay. However, owing to various reasons, for example the appropriateness of the function used to fit the decay, or any recycling of $\mathrm{OH}$ from oxidation products (for example the reaction of $\mathrm{HO}_{2}$ with $\mathrm{NO}$ ), it is prudent to characterise the instrument through the use of known concentrations of reactants for which the rate coefficient with $\mathrm{OH}$ is also well known. In order to validate measurements of ambient $\mathrm{OH}$ reactivity, the well-known rate coefficients for reactions of $\mathrm{OH}$ with $\mathrm{CO}$ and $\mathrm{CH}_{4}$ were both measured under pseudo-first-order conditions using the instrumental setup described above. Ultra-high purity air (BTCA 178, BOC Special Gases) was mixed with an excess of either $\mathrm{CO}$ (5\% in $\mathrm{N}_{2}$, BOC Special Gases) or $\mathrm{CH}_{4}$ (BOC, CP grade, $99.5 \%$ ), producing a main flow of 11.5 standard $\mathrm{L} \mathrm{min}^{-1}$ with known concentrations of $\mathrm{CO}$ or $\mathrm{CH}_{4}$, prior to mixing with a small flow of humidified air $\left(0.5\right.$ standard $\left.\mathrm{L} \mathrm{min}^{-1}\right)$ containing $\sim 50 \mathrm{ppb}_{3}$ generated by passing the air flow across a mercury vapour lamp.

Figure 4 shows the $\mathrm{OH}$ reactivity, determined by fitting Eq. (5) to the $\mathrm{OH}$ decay and subtracting $k_{\text {phys }}$ (Sect. 3), for a series of $\mathrm{CO}$ and $\mathrm{CH}_{4}$ concentrations. The bimolecular rate coefficients for $\mathrm{OH}+\mathrm{CO}$ $\left(k_{\mathrm{OH}+\mathrm{CO}}\right)$ and $\mathrm{OH}+\mathrm{CH}_{4}\left(k_{\mathrm{OH}}+\mathrm{CH}_{4}\right)$, determined at $298 \mathrm{~K}$ from the relationships $k_{\mathrm{OH}}^{\prime}=k_{\mathrm{OH}+\mathrm{CO}}[\mathrm{CO}]$ and $k_{\mathrm{OH}}^{\prime}=k_{\mathrm{OH}}+\mathrm{CH}_{4}\left[\mathrm{CH}_{4}\right]$, were found to be $(2.4 \pm 0.2) \times 10^{-13}$ and $(6.4 \pm 0.6) \times 10^{-15} \mathrm{~cm}^{3} \mathrm{~s}^{-1}$, respectively (errors are $1 \sigma$ ). The values for $k_{\mathrm{OH}}+\mathrm{CO}$ and $k_{\mathrm{OH}}+\mathrm{CH} 4$ determined here are in agreement with the literature values of $\left(2.3_{-0.5}^{+0.6}\right) \times 10^{-13}$ and $\left(6.4_{-1.1}^{+1.3}\right) \times 10^{-15} \mathrm{~cm}^{3} \mathrm{~s}^{-1}$ at $298 \mathrm{~K}$ (Atkinson et al., 2004), respectively, providing confidence in measurements of ambient $\mathrm{OH}$ reactivity.

\section{Limit of detection, precision and total uncertainty}

The instrumental limit of detection for measurements of $k_{\mathrm{OH}}^{\prime}$ is determined by the fit error in $k_{\text {loss }}$ (Eq. 5), the determination of $k_{\text {phys }}$, and its associated uncertainty, and the number of measurements used to determined $k_{\text {phys }}$. For the ClearfLo campaign, $k_{\text {phys }}$ was determined to be $(1.1 \pm 1.0) \mathrm{s}^{-1}$, with a precision of $0.4 \mathrm{~s}^{-1}$ and a $1 \sigma$ limit of detection for $k_{\mathrm{OH}}^{\prime}$ of $1.0 \mathrm{~s}^{-1}$. During the York campaign (Sect. 7), $k_{\text {phys }}$ was determined to be $(1.25 \pm 0.42) \mathrm{s}^{-1}$, with a precision of $0.2 \mathrm{~s}^{-1}$ and a $1 \sigma$ limit of detection for $k_{\mathrm{OH}}^{\prime}$ of $0.4 \mathrm{~s}^{-1}$.

Experiments described in Sect. 4 indicate that $\mathrm{OH}$ reactivities of up to $\sim 150 \mathrm{~s}^{-1}$ can be measured reliably with the instrument described in this work, with the possibility for measurements of higher reactivities described in Sect. 9 . Replicates of $k_{\mathrm{OH}}^{\prime}$ measurements at fixed concentrations of $\mathrm{CO}$ and $\mathrm{CH}_{4}$ (Sect. 4 and Fig. 4) also enable determination of the instrument precision. The majority of ambient $k_{\mathrm{OH}}^{\prime}$ measurements are $<35 \mathrm{~s}^{-1}$, for which the measurements under controlled conditions using known concentrations of $\mathrm{CO}$ and $\mathrm{CH}_{4}$ indicate a precision of $\sim 1 \mathrm{~s}^{-1}$. For reactivities of $\sim 110 \mathrm{~s}^{-1}$, which were observed in London during the ClearfLo campaign (Sect. 7, Whalley et al., 2016), measurements using known concentrations of $\mathrm{CO}$ and $\mathrm{CH}_{4}$ indicated a precision of $\sim 5 \mathrm{~s}^{-1}$. In the field, reactivities of up to $\sim 140 \mathrm{~s}^{-1}$ have also been measured, with fit errors of $\sim 6 \mathrm{~s}^{-1}$, although the precision at higher reactivities is worse compared to lower reactivities.

On average, the total uncertainty in measurements of $k_{\mathrm{OH}}^{\prime}$ is $6 \%$, with the uncertainty in $k_{\text {phys }}$ comprising $\sim 70 \%$ of the total uncertainty. When addition of $\mathrm{O}_{3}$ to the instrument is necessary to improve the $\mathrm{OH}$ signal (at ambient mixing ratios of $\mathrm{O}_{3}$ of less than $10 \mathrm{ppb}$ and during laboratory experiments and measurements of $k_{\text {phys }}$ ), the uncertainty associated with the dilution of the main flow contributes $\sim 25 \%$ to the total uncertainty in $k_{\mathrm{OH}}^{\prime}$.

\section{Potential interferences}

Potential interferences in measurements of $k_{\mathrm{OH}}^{\prime}$ were investigated through model simulations of $\mathrm{OH}$ decay traces under various scenarios to investigate the possible effects of $\mathrm{OH}$ recycling, and subsequent impacts on measurements of $k_{\mathrm{OH}}^{\prime}$, through the reaction of ambient $\mathrm{NO}$ with any $\mathrm{HO}_{2}$ or $\mathrm{RO}_{2}$ radicals that may be generated within the instrument.

The initial $\mathrm{OH}$ concentration in the instrument, following photolysis of $\mathrm{O}_{3}$ by the $266 \mathrm{~nm}$ laser, is estimated at $>3 \times 10^{10} \mathrm{~cm}^{-3}$ (Sect. 2.5), with no co-production of $\mathrm{HO}_{2}$ following photolysis of $\mathrm{O}_{3}$. However, there is production of $\mathrm{HO}_{2}$ from the reaction of $\mathrm{OH}$ with $\mathrm{CO}$ in the instrument, and of $\mathrm{RO}_{2}$ radicals from the reactions of $\mathrm{OH}$ with VOCs. The $\mathrm{HO}_{2}$ radicals produced have the potential to recycle $\mathrm{OH}$ through reactions with $\mathrm{NO}$, which would lead to an apparent reduction in the observed $\mathrm{OH}$ reactivity. In addition, there is potential for production of $\mathrm{HO}_{2}$ from the photolysis of oxygenated volatile organic compounds (oVOCs) in the instrument, with previous studies indicating significant radical production following photolysis of oVOCs in urban environments (Volkamer et al., 2010; Sheehy et al., 2010). During the ClearfLo campaign in London (Sect. 7), the mean observed $\mathrm{HCHO}$ mixing ratio was $9.3 \mathrm{ppb}$, potentially leading to production of $\sim 1 \times 10^{8} \mathrm{~cm}^{-3} \mathrm{HO}_{2}$ following the photolysis of $\mathrm{HCHO}$ at $266 \mathrm{~nm}$ within the reactivity instrument. Other oVOCs, notably $\mathrm{CH}_{3} \mathrm{CHO}, \mathrm{C}_{3} \mathrm{H}_{7} \mathrm{CHO}$, IPRCHO $\left(\left(\mathrm{CH}_{3}\right)_{2} \mathrm{CHO}\right), \mathrm{C}_{4} \mathrm{H}_{9} \mathrm{CHO}$, methacrolein (MACR) and methyl vinyl ketone (MVK) during the ClearfLo campaign, are also potentially photolysed by the $266 \mathrm{~nm}$ laser 

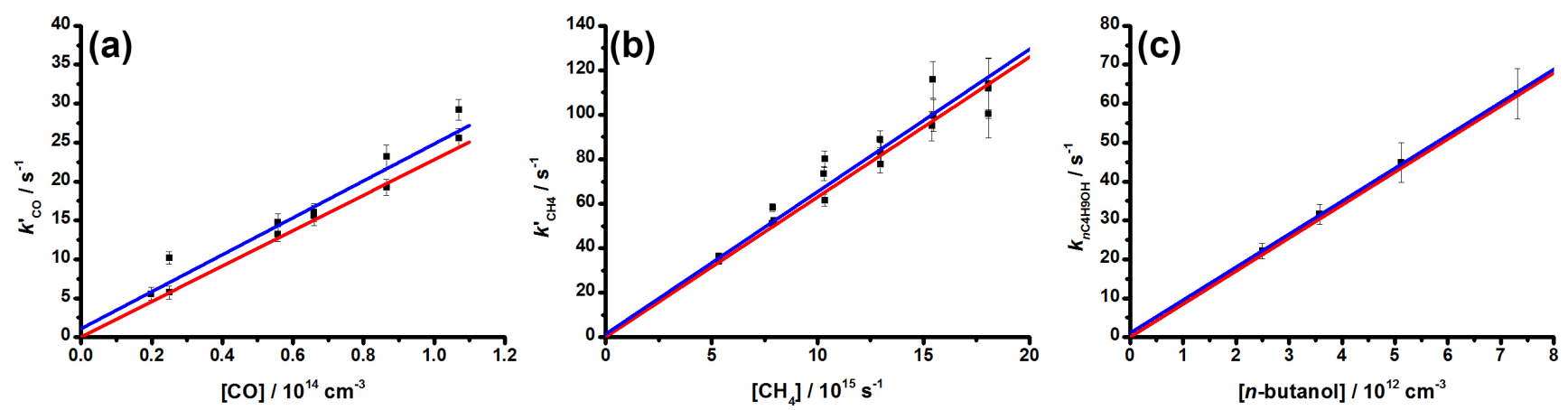

Figure 4. Bimolecular plots of pseudo-first-order rate coefficients describing $\mathrm{OH}$ loss $\left(k_{\mathrm{OH}}^{\prime}\right)$ against known concentrations of reactive gases

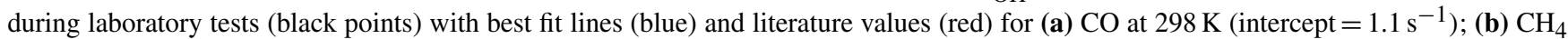
at $298 \mathrm{~K}$ (intercept $\left.=1.3 \mathrm{~s}^{-1}\right)$; $\left(\right.$ c) $n$-butanol $\left(n-\mathrm{C}_{4} \mathrm{H}_{9} \mathrm{OH}\right.$, sampling from the chamber) at $298 \mathrm{~K}$ (intercept $\left.=1.1 \mathrm{~s}^{-1}\right)$. Literature values are taken from Atkinson et al. (2004). Corrections for dilution have been applied (Eq. 7). Errors are $1 \sigma$ from the fits to the observed OH decays. Note the change in vertical scale between the three panels.

in the $\mathrm{OH}$ reactivity instrument, leading to production of $\mathrm{HO}_{2}$. For the mean oVOC mixing ratios observed during ClearfLo, and literature absorption cross-sections at $266 \mathrm{~nm}$ (Atkinson et al., 2004), there is potential for production of $\sim 2.5 \times 10^{8} \mathrm{~cm}^{-3} \mathrm{HO}_{2}$ in the reactivity instrument, including that produced by photolysis of $\mathrm{HCHO}$, with $\mathrm{CH}_{3} \mathrm{CHO}$ representing the dominant oVOC photolysed. The effects of $\mathrm{HO}_{2}$ and $\mathrm{RO}_{2}$ radicals produced by $\mathrm{OH}$ reactions within the instrument, and of $\mathrm{HO}_{2}$ production following oVOC photolysis, were therefore investigated over a range of NO mixing ratios.

Model simulations, using the numerical integration package Kintecus (Ianni, 2002), were initiated with a conservative estimate of the initial $\mathrm{OH}$ radical concentration of $1 \times 10^{10} \mathrm{~cm}^{-3}$ and a total $\mathrm{OH}$ reactivity of $25 \mathrm{~s}^{-1}$ comprised of losses to $\mathrm{CO}$ (producing $\mathrm{HO}_{2}$ ), VOCs (producing $\mathrm{RO}_{2}$ ) and $\mathrm{NO}_{2}$ (leading to loss of radicals from the system). The relative contributions of $\mathrm{CO}$ and VOCs to the total $\mathrm{OH}$ reactivity (7 and $68 \%$, respectively) were set to the average values determined by Whalley et al. (2016) for field measurements in London (Sect. 7). The contribution from $\mathrm{NO}_{2}$ was set to increase with increasing $\mathrm{NO}$ in the model with the $\mathrm{NO}_{2}$ : NO ratio set to the average ratio observed during measurements in London (Bohnenstengel et al., 2015; Whalley et al., 2016), and the model includes the reaction between $\mathrm{HO}_{2}$ and $\mathrm{NO}_{2}$ to form $\mathrm{HO}_{2} \mathrm{NO}_{2}$, and the reverse reaction (which is slow and negligible on the timescale of the reactivity measurement). Initial concentrations of $\mathrm{HO}_{2}$ were, in separate model simulations, set to $0,1 \times 10^{8}$ and $2.5 \times 10^{8} \mathrm{~cm}^{-3}$ to investigate the potential effects of oVOC photolysis. Initial mixing ratios of $\mathrm{NO}$ were varied from zero to $75 \mathrm{ppb}$, the maximum observed during field measurements of $k_{\mathrm{OH}}^{\prime}$ in London in 2012 (Whalley et al., 2016). The model was run forwards in time and output for $\mathrm{OH}$ was analysed in an identical manner to that applied to the $\mathrm{OH}$ decays measured by the reactivity instrument to determine $k_{\mathrm{OH}}^{\prime}$. Comparison of the values for $k_{\mathrm{OH}}^{\prime}$ determined by fitting to the simulated $\mathrm{OH}$ decays to the total reactivity input to the model thus enables assessment of any potential interferences.

Figure 5 shows the impact of $\mathrm{NO}$ on the $\mathrm{OH}$ reactivity determined by fitting to the model output for $\mathrm{OH}$. For model simulations with the initial concentration of $\mathrm{HO}_{2}$ set to zero (i.e. no photolytic sources of $\mathrm{HO}_{2}$ ), but with subsequent generation of $\mathrm{HO}_{2}$ following reaction of $\mathrm{OH}$ with $\mathrm{CO}$, it can be seen that the $\mathrm{OH}$ reactivity determined by fitting to the model output for $\mathrm{OH}$ shows only a small deviation of from the true $\mathrm{OH}$ reactivity in the model, through the recycling of $\mathrm{OH}$ through $\mathrm{HO}_{2}+\mathrm{NO}$. At $75 \mathrm{ppb}$ of NO, the deviation from the true $\mathrm{OH}$ reactivity is $\sim 4 \%$, which is less than the overall uncertainty in measurements of $k_{\mathrm{OH}}^{\prime}$. For model runs which simulate photolytic production of $\mathrm{HO}_{2}$ from oVOCs, with initial $\mathrm{HO}_{2}$ concentrations of $1.0 \times 10^{8}$ or $2.5 \times 10^{8} \mathrm{~cm}^{-3}$, it can be seen that the impact of $\mathrm{OH}$ recycling through $\mathrm{HO}_{2}+\mathrm{NO}$ is dependent on the initial $\mathrm{OH}$ concentration. For initial $\mathrm{OH}$ concentrations of $10^{9} \mathrm{~cm}^{-3}$, the impact of photolytic $\mathrm{HO}_{2}$ production is potentially large, with a deviation of $18 \%$ from the true reactivity for an initial $\mathrm{HO}_{2}$ concentration of $1.0 \times 10^{8} \mathrm{~cm}^{-3}$ and a deviation of $10 \%$ for an initial $\mathrm{HO}_{2}$ concentration of $2.5 \times 10^{8} \mathrm{~cm}^{-3}$ at $75 \mathrm{ppb}$ of NO. However, as discussed in Sect. 2.5, the initial $\mathrm{OH}$ concentration produced in the instrument is expected to be significantly higher than $10^{9} \mathrm{~cm}^{-3}$. For an initial $\mathrm{OH}$ concentration of $10^{10} \mathrm{~cm}^{-3}$, which is still a conservative estimate of the initial $\mathrm{OH}$ concentration, the impact of any photolytically generated $\mathrm{HO}_{2}$ is minimal, with the deviation from the expected $\mathrm{OH}$ reactivity at $75 \mathrm{ppb}$ of $\mathrm{NO}$ similar to that determined in the absence of any photolytically produced $\mathrm{HO}_{2}$ at $\sim 5 \%$. However, we note that it is not possible to fully assess the impact of unmeasured or unknown oVOCs, and recommend maintaining high initial $\mathrm{OH}$ concentrations in the reactivity instrument in order to maximise the $\mathrm{OH}: \mathrm{HO}_{2}$ ra- 


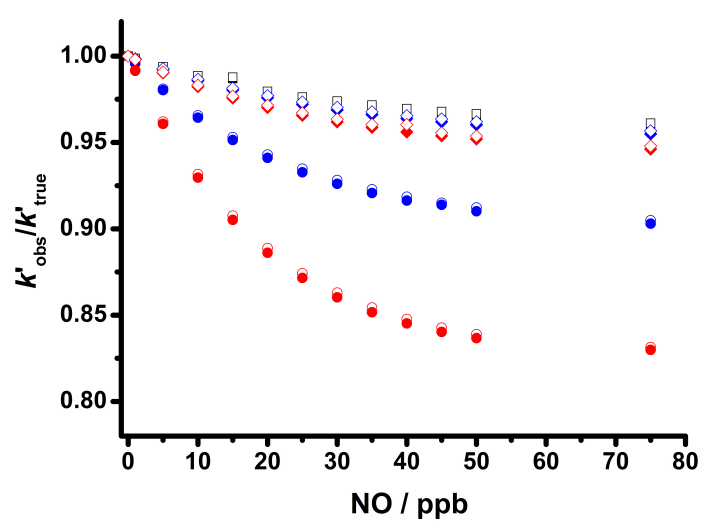

Figure 5. Impact of $\mathrm{NO}$ on the ratio of the $k_{\mathrm{OH}}^{\prime}$ fitted to model simulations for $\mathrm{OH}$ to the $k_{\mathrm{OH}}^{\prime}$ used as input for the model (i.e. the equivalent of $k_{\text {observed }}^{\prime} / k_{\text {true }}^{\prime}$ ). Black points show results for model simulations with the initial $\mathrm{HO}_{2}$ concentration set to zero; blue data points show results for model simulations with the initial $\mathrm{HO}_{2}$ concentration set to $1 \times 10^{8} \mathrm{~cm}^{-3}$; red data points show results for model simulations with the initial $\mathrm{HO}_{2}$ concentration set to $2.5 \times 10^{8} \mathrm{~cm}^{-3}$; circles represent data points with an initial $\mathrm{OH}$ concentration of $10^{9} \mathrm{~cm}^{-3}$; diamonds represent data points with an initial $\mathrm{OH}$ concentration of $10^{10} \mathrm{~cm}^{-3}$; filled data points represent simulations with the initial $\mathrm{RO}_{2}$ concentration set to zero; open data points represent simulations with an initial $\mathrm{RO}_{2}$ concentration of $1 \times 10^{10} \mathrm{~cm}^{-3}$.

tio and thereby minimise any potential interferences arising from production of $\mathrm{HO}_{2}$ in the instrument.

Model simulations were also performed with an initial $\mathrm{RO}_{2}$ concentration of $1 \times 10^{10} \mathrm{~cm}^{-3}$ to investigate the possible effects of incompletely refreshing the gas sample in the reactivity instrument between photolysis pulses, which could potentially lead to increased $\mathrm{RO}_{2}$ concentrations in the reaction cell through $\mathrm{OH}+\mathrm{VOC}$ reactions. A reaction between $\mathrm{RO}_{2}$ and $\mathrm{OH}$ was also added to the model, with a rate coefficient of $1 \times 10^{-10} \mathrm{~cm}^{3} \mathrm{~s}^{-1}$, as observed for $\mathrm{CH}_{3} \mathrm{O}_{2}+\mathrm{OH}$ (Bossolasco et al., 2014) and $\mathrm{C}_{2} \mathrm{H}_{5} \mathrm{O}_{2}+\mathrm{OH}$ (Farago et al., 2015). Figure 5 shows that the impact of $\mathrm{RO}_{2}$ chemistry within the instrument is not expected to have a significant impact on the observed $\mathrm{OH}$ reactivity, with the potential increase in observed $\mathrm{OH}$ reactivity of $1 \mathrm{~s}^{-1}$ from an initial $\mathrm{RO}_{2}$ concentration of $1 \times 10^{10} \mathrm{~cm}^{-3}$ and $k_{\mathrm{RO}_{2}}+\mathrm{OH}=1 \times 10^{-10} \mathrm{~cm}^{3} \mathrm{~s}^{-1}$, being less than the total uncertainty in ambient measurements of $k_{\mathrm{OH}}^{\prime}$. In addition, experiments in which the pulse repetition frequency of the photolysis laser was varied between 0.1 and $1 \mathrm{~Hz}$, thus varying the extent to which the gas sample was replaced between laser pulses, did not show any significant change in the observed $\mathrm{OH}$ reactivity. Despite the expectation that the impact of $\mathrm{OH}+\mathrm{RO}_{2}$ chemistry on observations of $k_{\mathrm{OH}}^{\prime}$ will be minimal, we include an additional $1 \mathrm{~s}^{-1}$ uncertainty in ambient measurements of $k_{\mathrm{OH}}^{\prime}$ to reflect the potential for interferences owing to $\mathrm{RO}_{2}$ production in the reactivity instrument. We note that the contribution to the uncertainty in the total
$\mathrm{OH}$ reactivity from $\mathrm{RO}_{2}+\mathrm{OH}$ chemistry is itself subject to significant uncertainty and the additional $1 \mathrm{~s}^{-1}$ uncertainty applied to the total $\mathrm{OH}$ reactivity represents an upper limit which is included in order to be thorough and complete.

We thus conclude that the reactivity instrument described in this work does not suffer from significant interferences associated with potential production of $\mathrm{HO}_{2}$ or $\mathrm{RO}_{2}$ within the instrument. We do note, however, that measurements of $\mathrm{OH}$ reactivity using this instrument in environments which may contain significant concentrations of oVOCs would benefit from high initial concentrations of $\mathrm{OH}$. We also note that any $\mathrm{OH}$ decays observed during field or laboratory experiments that cannot be reliably fitted by a single exponential function describing a first-order loss for $\mathrm{OH}$ (Eq. 5) would be treated with caution and, where appropriate, other fitting functions would be applied.

\section{Field measurements}

The laser flash photolysis $\mathrm{OH}$ reactivity instrument was deployed at the North Kensington measurement site $\left(51^{\circ} 31^{\prime} \mathrm{N}\right.$, $0^{\circ} 12^{\prime} \mathrm{W}$ ) during the Clean Air for London (ClearfLo) summer campaign in July and August 2012 (Bohnenstengel et al., 2014), with near-continuous measurements made from the 21 July to 18 August 2012, alongside FAGE measurements of $\mathrm{OH}, \mathrm{HO}_{2}$ and $\mathrm{RO}_{2}$ radical concentrations. Measurements of $\mathrm{O}_{3}, \mathrm{CO}, \mathrm{NO}, \mathrm{NO}_{2}, \mathrm{HONO}$, VOCs and aerosol mass and composition were also made at the site during the campaign.

Figure 6 shows the full time series of measured $\mathrm{OH}$ reactivity for the campaign. The observed reactivity was highest for air masses that had previously passed over central London (24-27 July (Julian days 206-209) and 8-10 August (Julian days 221-223)), with a maximum reactivity of $116 \mathrm{~s}^{-1}$ recorded during rush hour on 24 July 2012. Measurements taken on the 25 July 2012 (Julian day 207) are shown in Fig. 7 to highlight the capability of the instrument, and the average diurnal profile for the campaign is shown in Fig. 8 . A peak reactivity, on average, of $\sim 27 \mathrm{~s}^{-1}$ was observed during morning rush hour, with a minimum of $\sim 15 \mathrm{~s}^{-1}$ during the afternoon and a second peak during evening rush hour. Detailed analysis of these data, including model calculations using the Master Chemical Mechanism constrained to observed concentrations of long-lived species, is described by Whalley et al. (2016). The modelling study shows that the observed $\mathrm{OH}$ reactivity can be reproduced by the model (to within $6 \%$ ) when larger VOCs than those typically measured are included in the model, and demonstrates the importance of oxidation intermediates and the role of heavy VOCs, particularly biogenics, in controlling the total $\mathrm{OH}$ reactivity and the oxidation budget in a megacity such as London.

Field measurements of $\mathrm{OH}$ reactivity have also been made at a site at the University of York $\left(53^{\circ} 56^{\prime} \mathrm{N}, 1^{\circ} 02^{\prime} \mathrm{W}\right)$ from the 19 May to 16 June 2014, approximately $3 \mathrm{~km}$ southeast of the centre of York and $2 \mathrm{~km}$ west of a major road, 


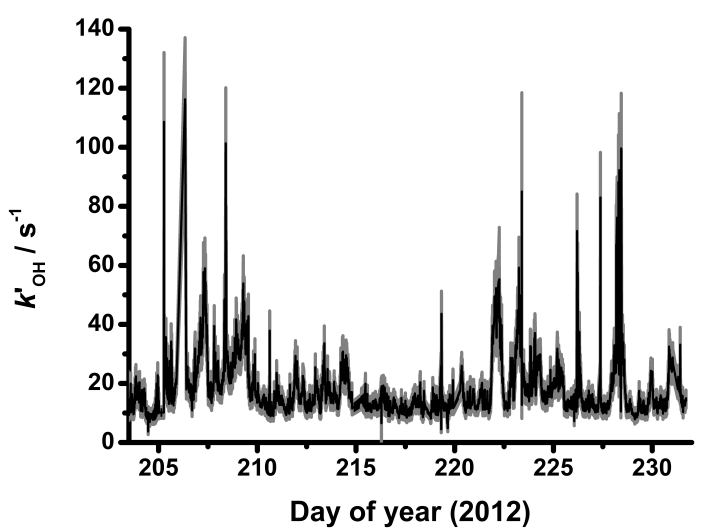

Figure 6. Time series of $\mathrm{OH}$ reactivity observed during the Clean Air for London (ClearfLo) campaign (21 July to 18 August 2012). Uncertainties (represented by the shaded area) represent $1 \sigma$ combined uncertainties from the fits to observed $\mathrm{OH}$ decays (Eq. 5), determinations of $k_{\text {phys }}$ (Eq. 6) and uncertainties in the dilution factor, $f$ (Eq. 7).

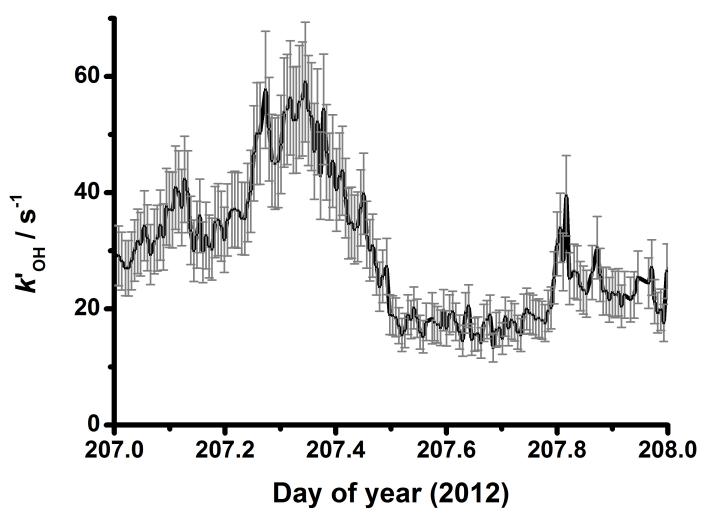

Figure 7. Time series of $\mathrm{OH}$ reactivity observed during the Clean Air for London (ClearfLo) campaign on the 25 July 2012 (Julian day 207). Error bars represent $1 \sigma$ combined uncertainties from the fits to observed $\mathrm{OH}$ decays (Eq. 5), determinations of $k_{\text {phys }}$ (Eq. 6) and uncertainties in the dilution factor, $f$ (Eq. 7).

with a small wooded area immediately to the east, and thus subject to anthropogenic emissions and local biogenic emissions. Figure 9 shows the average diurnal during this period. The observed $\mathrm{OH}$ reactivity was typically lower than that observed during the ClearfLo campaign, with a maximum in the diurnal average of $\sim 6 \mathrm{~s}^{-1}$. Measurements of $\mathrm{O}_{3}, \mathrm{CO}, \mathrm{NO}$, $\mathrm{NO}_{2}$, VOCs and were also made at the site during this period, alongside measurements by a new instrument coupling an $\mathrm{OH}$ reactor to measurements of VOCs by gas chromatography with time of flight mass spectrometry (GC-ToFMS) to aid identification of any "missing" $\mathrm{OH}$ reactivity. Detailed analysis of the results will be given in future publications.

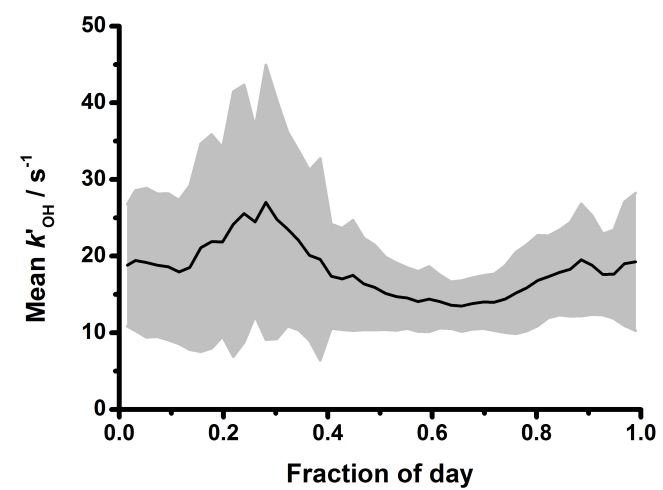

Figure 8. Diurnal average for observed $\mathrm{OH}$ reactivity (15 min averages) during the Clean Air for London (ClearfLo) campaign (21 July to 18 August). Shaded areas represent the measurement variability from day to day during the campaign.

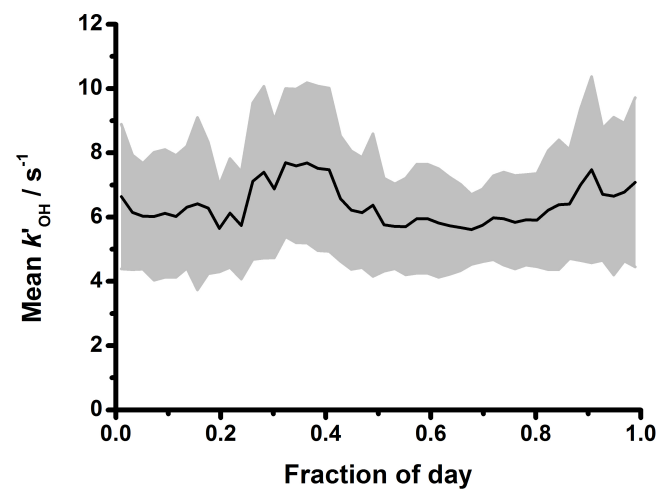

Figure 9. Diurnal average for observed $\mathrm{OH}$ reactivity (15 min averages) during in York (19 May to 16 June 2014). Shaded areas represent the measurement variability from day to day.

\section{Chamber measurements}

The field instrument described above has also been modified in order to interface to the Highly Instrumented Reactor for Atmospheric Chemistry (HIRAC) to enable measurements of $\mathrm{OH}$ reactivity during VOC oxidation under controlled conditions. For complex reaction mechanisms, the oxidation pathway followed will have a characteristic time-evolution of the reactivity as secondary products are generated, and measurement of $\mathrm{OH}$ reactivity and comparison with a model prediction provides greater constraint for experimental determination of the mechanism.

HIRAC is a $2.25 \mathrm{~m}^{3}$ stainless steel chamber equipped with UV photolysis lamps to initiate photochemistry and a comprehensive suite of analytical instrumentation, including gas chromatography (GC), Fourier transform infrared (FT-IR) spectroscopy, cavity ringdown spectroscopy (CRDS) and LIF-FAGE for radical measurements. Photolysis lamps within the chamber enable initiation of photochemistry, and experiments can be conducted at temperatures between 203 

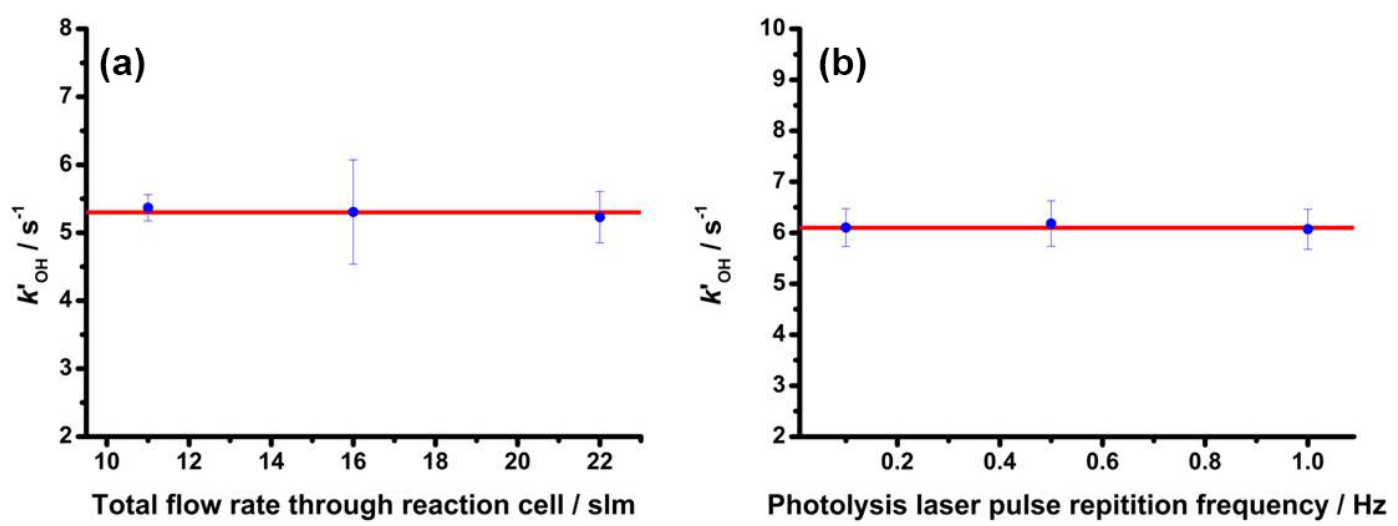

Figure 10. Observed $\mathrm{OH}$ reactivities for a fixed gas composition (for which the expected $\mathrm{OH}$ reactivity is shown in red) (a) as a function of the total flow rate through the reaction cell $\left(\mathrm{slm}=\right.$ standard $\left.\mathrm{L} \mathrm{min}^{-1}\right)$ and $(\mathbf{b})$ as a function of the pulse repetition frequency of the photolysis laser.

and $343 \mathrm{~K}$ and pressures up to 760 Torr (Glowacki et al., 2007; Malkin et al., 2010; Winiberg et al., 2015).

Gas is sampled from HIRAC through $1 / 2^{\prime \prime}$ PTFE tubing at a flow rate of 1 standard $\mathrm{L} \mathrm{min}^{-1}$ and diluted with 5 standard $\mathrm{L} \mathrm{min}^{-1}$ of ultra-high purity air immediately on exiting the chamber, then diluted further with 9 standard $\mathrm{L} \mathrm{min}^{-1}$ of humidified ultra-high purity air and 1 standard $\mathrm{L} \mathrm{min}^{-1}$ of ultra-high purity air passed over a low pressure $\mathrm{Hg}$ lamp in order to generate $\mathrm{O}_{3}$, giving a total flow of 16 standard $\mathrm{L} \mathrm{min}^{-1}$ and hence a dilution factor of $1: 16$. The diluted gas flow, containing $\sim 45 \mathrm{ppb} \mathrm{O}_{3}$, is then directed into the reaction cell of the $\mathrm{OH}$ reactivity instrument, with instrument operation and analysis as described in Sects. 2 and 3 (including the correction of observed reactivity for dilution of sampled gas from the chamber using Eq. (7), which is significant for these experiments in order to avoid measurement of high reactivities (Sect. 9) and to reduce the volume of gas removed from the chamber for the reactivity measurements). The uncertainty associated with the dilution contributes $\sim 25 \%$ to the total uncertainty in $k_{\mathrm{OH}}^{\prime}$, which is approximately $6-8 \%$.

Experiments were conducted to verify the sampling procedure by filling HIRAC with air containing known concentrations of a reactive gas, with a well-characterised rate coefficient for reaction with $\mathrm{OH}$, followed by measurement of the $\mathrm{OH}$ reactivity in the chamber. Determination of the pseudo-first-order rate coefficients describing the $\mathrm{OH}$ loss for each of the given reactive gas concentrations in the chamber enabled determination of the bimolecular rate coefficient for reaction of the reactive gas with $\mathrm{OH}$ for comparison with literature values, as for experiments described in Sect. 4. Figure 4c shows the bimolecular plots for experiments in which the chamber was filled with $n$ butanol $\left(n-\mathrm{C}_{4} \mathrm{H}_{9} \mathrm{OH}\right)$ in air at total pressures of 760 Torr and temperatures of $298 \mathrm{~K}$. A bimolecular rate coefficient of $(8.5 \pm 0.1) \times 10^{-12} \mathrm{~cm}^{3} \mathrm{~s}^{-1}$ was obtained, in comparison to the literature value of $\left(8.5_{-2.5}^{+3.5}\right) \times 10^{-12} \mathrm{~cm}^{3} \mathrm{~s}^{-1}$ (Atkinson et al., 2004), thus indicating the validity of the sampling procedure. No dependence of the observed reactivity was observed on the total flow rate through the instrument, which was varied between 10 and 22 standard $\mathrm{L} \mathrm{min}^{-1}$, or on the pulse repetition frequency of the photolysis laser, which was varied between 0.1 and $1 \mathrm{~Hz}$, as shown in Fig. 10.

The coupling of $\mathrm{OH}$ reactivity measurements to chamber studies will enable detailed assessment of our understanding of the chemistry of secondary products in complex oxidation mechanisms by providing increased constraint on oxidation budgets during chamber experiments, and will be explored further in future work.

\section{Effects of averaging time and future improvements to sampling}

Measurements have also been made in HIRAC to investigate the effect of the averaging time on the measured $\mathrm{OH}$ reactivity. Figure 11 shows the observed $\mathrm{OH}$ reactivities, for a given set of conditions, as a function of the averaging time, showing successful measurements with an averaging time of $10 \mathrm{~s}$ and indicating the potential for further improvements for future integration of ambient $\mathrm{OH}$ reactivity observations with flux measurements.

Experiments described in this work using known concentrations of reactive gases have been able to reproduce recommended literature values for known rate coefficients, indicating the validity of the technique described here over the dynamic ranges investigated. However, recent work in Leeds has shown that, at higher reactivities, observed kinetics can be influenced by sampling issues related to the effects of velocity distributions on the transport time of sampled gas from the pinhole nozzle to the point at which fluorescence is excited and detected in the FAGE cell. The effects of the velocity distributions on the time taken for sampled gas to travel from the pinhole to the point of detection coupled with the 


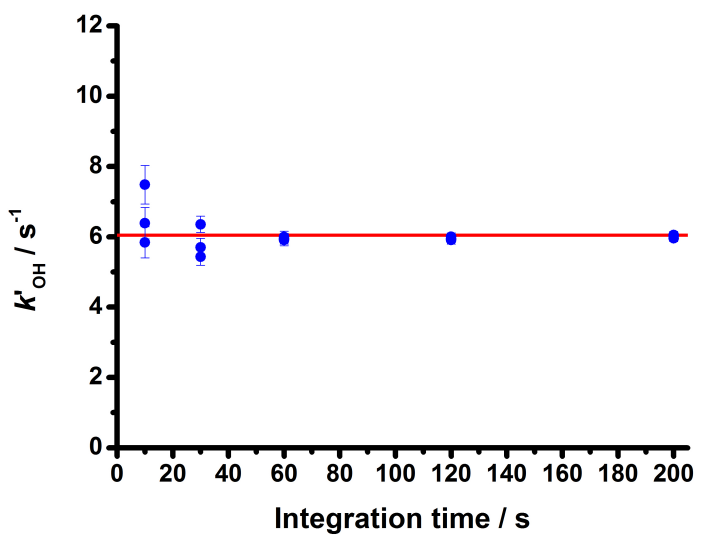

Figure 11. Observed $\mathrm{OH}$ reactivities, for a fixed gas composition (for which the expected $\mathrm{OH}$ reactivity is shown in red), as a function of averaging time, obtained using $15 \mathrm{~mW}$ of $308 \mathrm{~nm}$ probe laser power.

true kinetics of the $\mathrm{OH}$ decay can lead to underestimations of very high reactivities; this is described in detail by Stone et al. (2016). Successful measurements with known concentrations of $\mathrm{CH}_{4}$ at reactivities of $\sim 150 \mathrm{~s}^{-1}$ (Sect. 4, Fig. 4b), although scattered owing to the small number of time points over which fast decays can be measured and poorer precision compared to lower reactivities, indicate that such effects should be minimal for the instrument described in this work, even for the highest reactivities observed during the ClearfLo campaign $\left(>100 \mathrm{~s}^{-1}\right)$. However, experiments incorporating $\mathrm{OH}$ reactivity measurements in chamber studies, such as those described in Sect. 8, must also ensure that the gas sampled from the chamber has been sufficiently diluted so as to avoid the measurement of high reactivities directly.

Future work will incorporate a new inlet designed to minimise the distance between the pinhole nozzle and the point of excitation fluorescence and detection, ideally such that detection occurs within the supersonic jet formed on expansion of the gas as it flows through the pinhole. The new inlet will not only increase the dynamic range over which reactivity measurements can be made, but sampling within the supersonic jet will also lead to increased signal-to-noise and enable further reductions in the averaging time required to achieve adequate signal-to-noise for measurements with high time resolution.

\section{Conclusions and outlook}

In this work we present the design and characterisation of an instrument to make field and chamber measurements of $\mathrm{OH}$ reactivity by laser flash photolysis (LFP) coupled with laserinduced fluorescence (LIF) using the FAGE technique. The LFP-LIF reactivity instrument, its operation and data analysis have been described in detail. Ambient reactivity measurements obtained during field campaigns in London, UK, and York, UK, have been presented, and will be discussed further in future work. The instrument has also been coupled to an atmospheric chamber, and preliminary results have been shown to demonstrate the potential for reactivity measurements during future chamber experiments.

Reactivity measurements have been made using an averaging time of $10 \mathrm{~s}$, indicating potential for integration of ambient $\mathrm{OH}$ reactivity observations with flux measurements. Future development of the instrument will increase the dynamic range over which measurements can be made and will enable reduced averaging times owing to improvements in the signal-to-noise ratio.

Acknowledgements. This work was supported by the National Environment Research Council (NERC) under grants NE/H003193/1, NE/J008990/1 and NE/L010798/1. D. Stone is grateful to NERC for the award of an Independent Research Fellowship (NE/L010798/1). C. A. Brumby is grateful to the Engineering and Physical Sciences Research Council (EPSRC) for support. We are also thankful to the National Centre for Atmospheric Science (NCAS), which is funded by NERC, for ongoing support.

Edited by: R. Volkamer

\section{References}

Amedro, D., Miyazaki, K., Parker, A., Schoemaceker, C., and Fittschen, C.: Atmospheric and kinetic studies of $\mathrm{OH}$ and $\mathrm{HO}_{2}$ by the FAGE technique, J. Environ. Sci., 24, 78-86, 2012.

Atkinson, R., Baulch, D. L., Cox, R. A., Crowley, J. N., Hampson, R. F., Hynes, R. G., Jenkin, M. E., Rossi, M. J., and Troe, J.: Evaluated kinetic and photochemical data for atmospheric chemistry: Volume $\mathrm{I}-$ gas phase reactions of $\mathrm{O}_{x}, \mathrm{HO}_{x}, \mathrm{NO}_{x}$ and $\mathrm{SO}_{x}$ species, Atmos. Chem. Phys., 4, 1461-1738, doi:10.5194/acp-41461-2004, 2004.

Bloss, W. J., Gravestock, T. J., Heard, D. E., Ingham, T., Johnson, G. P., and Lee, J. D.: Application of a compact all solid-state laser system to the in situ detection of atmospheric $\mathrm{OH}, \mathrm{HO}_{2}, \mathrm{NO}$ and IO by laser-induced fluorescence, J. Environ. Monit., 5, 21-28, 2003.

Bohnenstengel, S. I., Belcher, S. E., Aiken, A. C., Allan, J. D., Allen, G., Bacak, A., Bannan, T. J., Barlow, J. F., Beddows, D. C. S., Bloss, W. J., Booth, A. M., Chemel, C., Coceal, O., Di Marco, C. F., Mavendra, D. K., Faloon, K. H., Fleming, Z., Furger, M., Gietl, J. K., Graves, R. R., Green, D. C., Grimmond, C. S. B., Halios, C., Hamilton, J. F., Harrison, R. M., Heal, M. R., Heard, D. E., Helfter, C., Herndon, S. C., Holmes, R. E., Hopkins, J. R., Jones, A. M., Kelly, F. J., Kotthaus, S., Langford, B., Lee, J. D., Leigh, R., Lewis, A. C., Lidster, R. T., Lopez-Hilfiker, F., McQuaid, J. B., Mohr, C., Monks, P. S., Nemitz, E., Ng, N. L., Percival, C. J., Prévôt, A. S. H., Ricketts, H. M. A., Sokhi, R., Stone, D., Thornton, J. A., Tremper, A. H., Valach, A. C., Visser, S., Whalley, L. K., Williams, L. R., Xu, L., Young, D. E., and Zotter, P.: Meteorology, air quality, and health in London: The ClearfLo project, Bull. Am. Meteor. Soc., 96, 779-804, doi:10.1175/BAMS-D-12-00245.1, 2015. 
Bossolasco, A., Farago, E. P., Schoemaecker, C., and Fittschen, C.: Rate constant of the reaction between $\mathrm{CH}_{3} \mathrm{O}_{2}$ and $\mathrm{OH}$ radicals, Chem. Phys. Lett., 593, 7-13, 2014.

Cantrell, C. A., Shetter, R. E., Calvert, J. G., Eisele, F. L., and Tanner, D. J.: Some considerations of the origin of nighttime peroxy radicals observed in MLOPEX, J. Geophys. Res.-Atmos., 102, 15899-15913, 1997.

Chatani, S., Shimo, N., Matsunaga, S., Kajii, Y., Kato, S., Nakashima, Y., Miyazaki, K., Ishii, K., and Ueno, H.: Sensitivity analyses of $\mathrm{OH}$ missing sinks over Tokyo metropolitan area in the summer of 2007, Atmos. Chem. Phys., 9, 8975-8986, doi:10.5194/acp-9-8975-2009, 2009.

Commane, R., Floquet, C. F. A., Ingham, T., Stone, D., Evans, M. J., and Heard, D. E.: Observations of $\mathrm{OH}$ and $\mathrm{HO}_{2}$ radicals over West Africa, Atmos. Chem. Phys., 10, 8783-8801, doi:10.5194/acp-10-8783-2010, 2010.

Creasey, D. J., Heard, D. E., and Lee, J. D.: Absorption Crosssection measurements of $\mathrm{O}_{2}$ and $\mathrm{H}_{2} \mathrm{O}$ at $185 \mathrm{~nm}$. Implications for the calibration of field instruments to measure $\mathrm{OH}, \mathrm{HO}_{2}$ and $\mathrm{RO}_{2}$ radicals, Geophys. Res. Lett., 27, 1651-1654, 2000.

Di Carlo, P., Brune, W. H., Martinez, M., Harder, H., Lesher, R., Ren, X., Thornberry, T., Carroll, M. A., Young, V., Shepson, P. B., Reimer, D., Apel, E., and Campbell, C.: Missing OH Reactivity in a Forest: Evidence for Unknown Reactive Biogenic VOCs, Science, 304, 722-725, 2004.

Dolgorouky, C., Gros, V., Sarda-Esteve, R., Sinha, V., Williams, J., Marchand, N., Sauvage, S., Poulain, L., Sciare, J., and Bonsang, B.: Total OH reactivity measurements in Paris during the 2010 MEGAPOLI winter campaign, Atmos. Chem. Phys., 12, 95939612, doi:10.5194/acp-12-9593-2012, 2012.

Edwards, P. M., Evans, M. J., Furneaux, K. L., Hopkins, J., Ingham, T., Jones, C., Lee, J. D., Lewis, A. C., Moller, S. J., Stone, D., Whalley, L. K., and Heard, D. E.: OH reactivity in a South East Asian tropical rainforest during the Oxidant and Particle Photochemical Processes (OP3) project, Atmos. Chem. Phys., 13, 9497-9514, doi:10.5194/acp-13-9497-2013, 2013.

Farago, E. P., Schoemaecker, C., Viskolcz, B., and Fittschen, C.: Experimental determination of the rate constant between $\mathrm{C}_{2} \mathrm{H}_{5} \mathrm{O}_{2}$ and $\mathrm{OH}$ radicals, Chem. Phys. Lett., 619, 196-200, 2015.

Fuchs, H., Hofzumahaus, A., Rohrer, F., Bohn, B., Brauers, T., Dorn, H.-P., Haseler, R., Holland, F., Kaminski, M., Li, X., Lu, K., Nehr, S., Tillmann, R., Wegener, R., and Wahner, A.: Experimental evidence for efficient hydroxyl radical regeneration in isoprene oxidation, Nat. Geosci., 6, 1023-1026, 2013.

Glowacki, D. R., Goddard, A., Hemavibool, K., Malkin, T. L., Commane, R., Anderson, F., Bloss, W. J., Heard, D. E., Ingham, T., Pilling, M. J., and Seakins, P. W.: Design of and initial results from a Highly Instrumented Reactor for Atmospheric Chemistry (HIRAC), Atmos. Chem. Phys., 7, 5371-5390, doi:10.5194/acp7-5371-2007, 2007.

Hansen, R. F., Griffith, S. M., Dusanter, S., Rickly, P. S., Stevens, P. S., Bertman, S. B., Carroll, M. A., Erickson, M. H., Flynn, J. H., Grossberg, N., Jobson, B. T., Lefer, B. L., and Wallace, H. W.: Measurements of total hydroxyl radical reactivity during CABINEX 2009 - Part 1: field measurements, Atmos. Chem. Phys., 14, 2923-2937, doi:10.5194/acp-14-2923-2014, 2014.

Ianni, J. C.: Kintecus, Windows Version 2.80, available at: www. kintecus.com (last access: 30 Aptil 2016), 2002.
Ingham, T., Goddard, A., Whalley, L. K., Furneaux, K. L., Edwards, P. M., Seal, C. P., Self, D. E., Johnson, G. P., Read, K. A., Lee, J. D., and Heard, D. E.: A flow-tube based laser-induced fluorescence instrument to measure $\mathrm{OH}$ reactivity in the troposphere, Atmos. Meas. Tech., 2, 465-477, doi:10.5194/amt-2-465-2009, 2009.

Kim, S., Guenther, A., Karl, T., and Greenberg, J.: Contributions of primary and secondary biogenic VOC tototal $\mathrm{OH}$ reactivity during the CABINEX (Community Atmosphere-Biosphere INteractions Experiments)-09 field campaign, Atmos. Chem. Phys., 11, 8613-8623, doi:10.5194/acp-11-8613-2011, 2011.

Kovacs, T. A. and Brune, W. H.: Total OH Loss Rate Measurement, J. Atmos. Chem., 39, 105-122, 2001.

Kovacs, T. A., Brune, W. H., Harder, H., Martinez, M., Simpas, J. B., Frost, G. J., Williams, E., Jobson, T., Stroud, C., Young, V., Fried, A., and Wert, B.: Direct measurements of urban $\mathrm{OH}$ reactivity during Nashville SOS in summer 1999, J. Environ. Monitor., 5, 68-74, 2003.

Lee, J. D., Young, J. C., Read, K. A., Hamilton, J. F., Hopkins, J. R., Lewis, A. C., Bandy, B. J., Davey, J., Edwards, P., Ingham, T., Self, D. E., Smith, S. C., Pilling, M. J., and Heard, D. E.: Measurement and calculation of $\mathrm{OH}$ reactivity at a United Kingdom coastal site, J. Atmos. Chem., 64, 53-76, 2009.

Lou, S., Holland, F., Rohrer, F., Lu, K., Bohn, B., Brauers, T., Chang, C. C., Fuchs, H., Häseler, R., Kita, K., Kondo, Y., Li, X., Shao, M., Zeng, L., Wahner, A., Zhang, Y., Wang, W., and Hofzumahaus, A.: Atmospheric $\mathrm{OH}$ reactivities in the Pearl River Delta - China in summer 2006: measurement and model results, Atmos. Chem. Phys., 10, 11243-11260, doi:10.5194/acp-10-11243-2010, 2010.

Lu, K. D., Hofzumahaus, A., Holland, F., Bohn, B., Brauers, T., Fuchs, H., Hu, M., Häseler, R., Kita, K., Kondo, Y., Li, X., Lou, S. R., Oebel, A., Shao, M., Zeng, L. M., Wahner, A., Zhu, T., Zhang, Y. H., and Rohrer, F.: Missing OH source in a suburban environment near Beijing: observed and modelled $\mathrm{OH}$ and $\mathrm{HO} 2$ concentrations in summer 2006, Atmos. Chem. Phys., 13, 10571080, doi:10.5194/acp-13-1057-2013, 2013.

Malkin, T. L., Goddard, A., Heard, D. E., and Seakins, P. W.: Measurements of $\mathrm{OH}$ and $\mathrm{HO}_{2}$ yields from the gas phase ozonolysis of isoprene, Atmos. Chem. Phys., 10, 1441-1459, doi:10.5194/acp-10-1441-2010, 2010.

Mao, J., Ren, X., Brune, W. H., Olson, J. R., Crawford, J. H., Fried, A., Huey, L. G., Cohen, R. C., Heikes, B., Singh, H. B., Blake, D. R., Sachse, G. W., Diskin, G. S., Hall, S. R., and Shetter, R. E.: Airborne measurement of $\mathrm{OH}$ reactivity during INTEX-B, Atmos. Chem. Phys., 9, 163-173, doi:10.5194/acp-9-163-2009, 2009.

Mao, J., Ren, X., Chen, S., Brune, W. H., Chen, Z., Martinez, M. Harder, H., Lefer, B., Rappenglück, B., Flynn, J., and Leuchner, M.: Atmospheric oxidation capacity in the summer of Houston 2006: Comparison with summer measurements in other metropolitan studies, Atmos. Environ., 44, 4107-4115, 2010.

Martinez, M., Harder, H., Kovacs, T. A., Simpas, J. B., Bassis, J., Lesher, R., Brune, W. H., Frost, G. J., Williams, E. J., Stroud, C. A., Jobson, B. T., Roberts, J. M., Hall, S. R., Shetter, R. E., Wert, B., Fried, A., Alicke, B., Stutz, J., Young, V. L., White, A. B., and Zamora, R. J.: $\mathrm{OH}$ and $\mathrm{HO}_{2}$ concentrations, sources, and loss rates during the Southern Oxidants Study in Nashville, 
Tennessee, summer 1999, J. Geophys. Res. Atmos., 108, 4617, 1-17, doi:10.1029/2003JD003551, 2003.

Matsumi, Y., Comes, F. J., Hancock, G., Hofzumahaus, A., Hynes, A. J., Kawasaki, M., and Ravishankara, A. R.: Quantum yields for production of $\mathrm{O}\left({ }^{1} \mathrm{D}\right)$ in the ultraviolet photolysis of ozone: Recommendation based on evaluation of laboratory data, J. Geophys. Res. Atmos., 107, 1-12, doi:10.1029/2001JD000510, 2002.

Michoud, V., Hansen, R. F., Locoge, N., Stevens, P. S., and Dusanter, S.: Detailed characterizations of the new Mines Douai comparative reactivity method instrument via laboratory experiments and modeling, Atmos. Meas. Tech., 8, 3537-3553, doi:10.5194/amt-8-3537-2015, 2015.

Mogensen, D., Smolander, S., Sogachev, A., Zhou, L., Sinha, V., Guenther, A., Williams, J., Nieminen, T., Kajos, M. K., Rinne, J., Kulmala, M., and Boy, M.: Modelling atmospheric OH-reactivity in a boreal forest ecosystem, Atmos. Chem. Phys., 11, 97099719, doi:10.5194/acp-11-9709-2011, 2011.

Nakashima, Y., Kamei, N., Kobayashi, S., and Kajii, Y.: Total OH reactivity and VOC analyses for gasoline vehicular exhaust with a chassis dynamometer, Atmos. Environ., 44, 468-475, 2010.

Nakashima, Y., Tsurumaru, H., Imamura, T., Bejan, I., Wenger, J. C., and Kajii, Y.: Total $\mathrm{OH}$ reactivity measurements in laboratory studies of the photooxidation of isoprene, Atmos. Environ., 62, 243-247, 2012.

Nakashima, Y., Kato, S., Greenberg, J., Harley, P., Karl, T., Turnipseed, A., Apel, E., Guenther, A., Smith, J., and Kajii, Y.: Total $\mathrm{OH}$ reactivity measurements in ambient air in a southern Rocky mountain ponderosa pine forest during BEACHONSRM08 summer campaign, Atmos. Environ., 85, 1-8, 2014.

Nölscher, A. C., Williams, J., Sinha, V., Custer, T., Song, W., Johnson, A. M., Axinte, R., Bozem, H., Fischer, H., Pouvesle, N., Phillips, G., Crowley, J. N., Rantala, P., Rinne, J., Kulmala, M., Gonzales, D., Valverde-Canossa, J., Vogel, A., Hoffmann, T., Ouwersloot, H. G., Vilà-Guerau de Arellano, J., and Lelieveld, J.: Summertime total $\mathrm{OH}$ reactivity measurements from boreal forest during HUMPPA-COPEC 2010, Atmos. Chem. Phys., 12, 8257-8270, doi:10.5194/acp-12-8257-2012, 2012.

Nölscher, A. C., Butler, T., Auld, J., Veres, P., Munoz, A., Taraborrelli, D., Vereecken, L., Leliveld, J., and Williams, J.: Using total $\mathrm{OH}$ reactivity to assess isoprene photooxidation via measurement and model, Atmos. Environ., 89, 453-463, 2014.

Ren, X., Harder, H., Martinez, M., Lesher, R. L., Oliger, A., Shirley, T., Adams, J., Simpas, J. B., and Brune, W. H.: HO $x$ concentrations and $\mathrm{OH}$ reactivity observations in New York City during PMTACS-NY2001, Atmos. Environ., 37, 3627-3637, 2003.

Ren, X., Brune, W. H., Mao, J. Q., Mitchell, M. J., Lesher, R. L., Simpas, J. B., Metcalf, A. R., Schwab, J. J., Cai, C. X., Li, Y. Q., Demerjian, K. L., Felton, H. D., Boynton, G., Adams, A., Perry, J., He, Y., Zhou, X. L., and Hou, J.: Behavior of $\mathrm{OH}$ and $\mathrm{HO}_{2}$ in the winter atmosphere in New York city, Atmos. Environ., 40, 252-263, 2006a.

Ren, X., Brune, W. H., Oliger, A., Metcalf, A. R., Simpas, J. B., Shirley, T., Schwab, J. J., Bai, C., Roychowdhury, U., Li, Y., Cai, C., Demerjian, K. L., He, Y., Zhou, X., Gao, H., and Hou, J.: $\mathrm{OH}, \mathrm{HO}_{2}$, and $\mathrm{OH}$ reactivity during the PMTACS-NY Whiteface Mountain 2002 campaign: Observations and model comparison, J. Geophys. Res., 111, D10S03, doi:10.1029/2005JD006126, $2006 b$.
Sadanaga, Y., Yoshino, A., Watanabe, K., Yoshioka, A., Wakazono, Y., Kanaya, Y., and Kajii, Y.: Development of a Measurement System of $\mathrm{OH}$ reactivity in the atmosphere using a laser-induced pump and probe technique, Rev. Sci. Instrum., 75, 2648-2655, 2004a.

Sadanaga, Y., Yoshino, A., Kato, S., Yoshioka, A., Watanabe, K., Miyakawa, Y., Hayashi, I., Ichikawa, M., Matsumoto, J., Nishiyama, A., Akiyama, N., Kanaya, Y., and Kajii, Y.: The importance of $\mathrm{NO}_{2}$ and volatile organic compounds in the urban air from the viewpoint of the $\mathrm{OH}$ reactivity, Geophys. Res. Lett., 31, L08102, doi:10.1029/2004g1019661, 2004b.

Sheehy, P. M., Volkamer, R., Molina, L. T., and Molina, M. J.: Oxidative capacity of the Mexico City atmosphere - Part 2: A ROx radical cycling perspective, Atmos. Chem. Phys., 10, 6993-7008, doi:10.5194/acp-10-6993-2010, 2010.

Shirley, T. R., Brune, W. H., Ren, X., Mao, J., Lesher, R., Cardenas, B., Volkamer, R., Molina, L. T., Molina, M. J., Lamb, B., Velasco, E., Jobson, T., and Alexander, M.: Atmospheric oxidation in the Mexico City Metropolitan Area (MCMA) during April 2003, Atmos. Chem. Phys., 6, 2753-2765, doi:10.5194/acp-62753-2006, 2006.

Sinha, V., Williams, J., Crowley, J. N., and Lelieveld, J.: The Comparative Reactivity Method - a new tool to measure total $\mathrm{OH}$ Reactivity in ambient air, Atmos. Chem. Phys., 8, 2213-2227, doi:10.5194/acp-8-2213-2008, 2008.

Sinha, V., Williams, J., Diesch, J. M., Drewnick, F., Martinez, M., Harder, H., Regelin, E., Kubistin, D., Bozem, H., HosaynaliBeygi, Z., Fischer, H., Andrés-Hernández, M. D., Kartal, D., Adame, J. A., and Lelieveld, J.: Constraints on instantaneous ozone production rates and regimes during DOMINO derived using in-situ $\mathrm{OH}$ reactivity measurements, Atmos. Chem. Phys., 12, 7269-7283, doi:10.5194/acp-12-7269-2012, 2012.

Stone, D., Whalley, L. K., and Heard, D. E.: Tropospheric OH and $\mathrm{HO}_{2}$ radicals: field measurements and model comparisons, Chem. Soc. Rev., 41, 6348-6404, 2012.

Stone, D., Blitz, M., Ingham, T., Onel, L., Medeiros, D. J. and Seakins, P. W.: An instrument to measure fast gas phase radical kinetics at high temperatures and pressures, Rev. Sci. Instr., 87, 054102, 1-9, doi:10.1063/1.4950906, 2016.

Volkamer, R., Sheehy, P., Molina, L. T., and Molina, M. J.: Oxidative capacity of the Mexico City atmosphere - Part 1: A radical source perspective, Atmos. Chem. Phys., 10, 6969-6991, doi:10.5194/acp-10-6969-2010, 2010.

Whalley, L. K., Furneaux, K. L., Goddard, A., Lee, J. D., Mahajan, A., Oetjen, H., Read, K. A., Kaaden, N., Carpenter, L. J., Lewis, A. C., Plane, J. M. C., Saltzman, E. S., Wiedensohler, A., and Heard, D. E.: The chemistry of $\mathrm{OH}$ and $\mathrm{HO}_{2}$ radicals in the boundary layer over the tropical Atlantic Ocean, Atmos. Chem. Phys., 10, 1555-1576, doi:10.5194/acp-10-1555-2010, 2010.

Whalley, L. K., Edwards, P. M., Furneaux, K. L., Goddard, A., Ingham, T., Evans, M. J., Stone, D., Hopkins, J. R., Jones, C. E., Karunaharan, A., Lee, J. D., Lewis, A. C., Monks, P. S., Moller, S. J., and Heard, D. E.: Quantifying the magnitude of a missing hydroxyl radical source in a tropical rainforest, Atmos. Chem. Phys., 11, 7223-7233, doi:10.5194/acp-11-7223-2011, 2011.

Whalley, L. K., Stone, D., Bandy, B., Dunmore, R., Hamilton, J. F., Hopkins, J., Lee, J. D., Lewis, A. C., and Heard, D. E.: Atmospheric $\mathrm{OH}$ reactivity in central London: observations, model predictions and estimates of in situ ozone production, Atmos. 
Chem. Phys., 16, 2109-2122, doi:10.5194/acp-16-2109-2016, 2016.

Winiberg, F. A. F., Smith, S. C., Bejan, I., Brumby, C. A., Ingham, T., Malkin, T. L., Orr, S. C., Heard, D. E., and Seakins, P. W.: Pressure-dependent calibration of the $\mathrm{OH}$ and $\mathrm{HO}_{2}$ channels of a FAGE HOx instrument using the Highly Instrumented Reactor for Atmospheric Chemistry (HIRAC), Atmos. Meas. Tech., 8, 523-540, doi:10.5194/amt-8-523-2015, 2015.

Yoshino, A., Sadanaga, Y., Watanabe, K., Kato, S., Miyakawa, Y., Matsumoto, J., and Kajii, Y.: Measurement of total $\mathrm{OH}$ reactivity by laser-induced pump and probe technique - comprehensive observations in the urban atmosphere of Tokyo, Atmos. Environ., 40, 7869-7881, 2006.
Yoshino, A., Nakashima, Y., Miyazaki, K., Kato, S., Suthawaree, J., Shimo, N., Matsunaga, S., Chatani, S., Apel, E., Greenberg, J., Guenther, A., Ueno, H., Sasaki, H., Hoshi, J., Yokota, H., Ishii, K., and Kajii, Y.: Air quality diagnosis from comprehensive observations of total $\mathrm{OH}$ reactivity and reactive trace species in urban central Tokyo, Atmos. Environ., 49, 51-59, 2012. 